\title{
Medicinal plants, aromatic herbs and spices as potent immunity defenders: Antiviral (COVID-19) perspectives
}

\author{
Nupur Mehrotra* \\ Department of Biochemistry, SVKM's Mithibai College of Arts, Chauhan Institute of Science \& Amrutben Jivanlal College of Commerce and \\ Economics (Autonomous), Vile-Parle (West), Mumbai-400056, Maharashtra, India
}

\section{Article Info}

Article history

Received 3 September 2020

Revised 26 October 2020

Accepted 29 October 2020

Published online 30 December 2020

\section{Keywords}

SARS-CoV-2

COVID-19

Medicinal plants

Aromatic herbs

Spices

Immunomodulators

\begin{abstract}
Global health is at risk due to the current SARS-CoV-2 pandemic which has posed a huge challenge. The virus has several protein spikes termed peplomers, on its surface, and is a positive-sense single-stranded RNA enveloped virus. The number of infected people across the globe is in an exponential phase in many of the 220 countries infected by the pandemic, and currently is in its second phase of infection at many places.
\end{abstract}

Scientists and researchers have set in a global race, the winning stride being successful discovery of a preventive vaccine and a specific treatment for COVID-19. Till such time, centers for ancient civilizations as India and China have intensified their search towards alternative medicine using herbal products, which hold immense pharmacological properties. In case of COVID-19, aromatic plants and herbs downregulate the pre-inflammatory mediators as IL-1, 6, 10 and 18 , TNF- $\alpha$ and NF- $\kappa$ B associated with the cytokine storm, which has proved to be fatal. Simultaneously, enhancement of expression of inducible nitric oxide synthase, production of IgG, IFN- $\gamma$ and IL-4 and activation of T helper cells, and NK cells, promises to provide protection along with therapeutic potential. These can be instrumental in enhancing the body's immune system along with strengthening and maintaining the health of the respiratory tract, the preferred host for the SARS-CoV-2. Such a modality can reach help to people who are immune compromised due to comorbidities as diabetes, hypertension, cancer, and other related disorders.

The present review focuses on reporting aromatic herbs, medicinal plants and spices with potential antiviral and immunomodulatory properties. To cater to the global health till such time that targeted drugs for the viral infection are made publicly available, these herbal remedies can surely be our best defenders.

\section{Introduction}

The entire globe has been startled by COVID-19 or the coronaviruses pandemic. Coronavirus is a RNA virus, belonging to the family Coronaviridae. Its nuclear material is positive-sense single-stranded RNA and it is an enveloped virus. 'Corona' is Latin in origin and refers to 'a crown or wreath', and the virus was so named on the appearance of infective form of virus which under an electron microscope appears to have multiple large surface projections or spikes making it appear like a crown or wreath. These projections are due to the proteinaceous viral spike peplomers. This class of virus until the outbreak of the severe acute respiratory syndrome (SARS) in the beginning of $21^{\text {st }}$ century (Guan et al., 2003) and the Middle East respiratory syndrome (MERS) in 2013 (Hemida, et al., 2013), was considered to largely affect the respiratory system and to some extent the gastrointestinal system in animals. These viruses lead to symptoms similar to pneumonia affecting respiratory system.

Corresponding author: Dr. Nupur Mehrotra Department of Biochemistry, SVKM's Mithibai College of Arts, Chauhan Institute of Science \& Amrutben Jivanlal College of Commerce and Economics (Autonomous), Bhaktivedanta Swami Marg, Vile Parle West, Mumbai-400056, Maharashtra, India

E-mail: nupur.mehrotra@mithibai.ac.in

Tel.: +91-9833452122

Copyright $(\mathcal{C} 2020$ Ukaaz Publications. All rights reserved.

Email: ukaaz@yahoo.com; Website: www.ukaazpublications.com
The SARS and MERS are believed to have been originated from bats and transmitted to humans through other animals like camels and civets (Cui et al., 2019; Hu et al., 2017). The viruses of this family depict large genetic diversity with high rate of recurrent recombination and great possibility of transmittance, thereby suggesting the emergence of variants of these viruses periodically.

November 2019 saw emergence of a new viral strain named SARS-CoV-2 or novel coronavirus or COVID-19, by International Committee on Taxonomy. This viral disease which has gripped the entire globe, originated from the market in Jianghan District, Wuhan, China which trades in live animals and seafood. Statistics suggest that more than 200 countries across all continents were rapidly infected with this virus within 3 months. World Health Organization (WHO) declared the disease, a pandemic in the second week of March 2020, whose symptoms were alike SARS (WHO, 2020). Globally as per $6^{\text {th }}$ December 2020 , the number of reported cases were $65,870,030$ with $1,523,583$ casualties as per WHO dashboard on COVID-19.

The main clinical manifestations of infection by SARS-Cov-2 studied in 1099 patients by Guan et al. (2020), from different areas in China, revealed that the dominant ones include fever and fatigue, sore throat and cough, shortness of breath, myalgia, headache, chills, and sputum production whereas few patients reported vomiting 
and diarrhea and associated gastrointestinal discomfort. An analysis of patients who contacted the disease suggests that the disease turned fatal in patients above 60 or ones with comorbidities as hypertension, diabetes, cancer, etc., with the number of male patients being higher than females. The rate of infection was elevated in patients with compromised immune system (Li et al., 2020; Hong Kong Centre for Health Protection, 2020; Gao et al., 2020). It was suggested that the best strategy to control and prevent infections were to build and maintain a strong immune system in the body. Thus, a healthy immune system with good holistic wellbeing are crucial factors for assuaging COVID-19 associated risks and increasing rate of survival as well as hastening recovery. Further, the need of the hour is to effectively adopt preventive therapeutic strategies to alleviate the risk of contracting COVID-19 infection till such times that effective antiviral drugs specific for COVID-19 or vaccine are designed, developed and delivered.

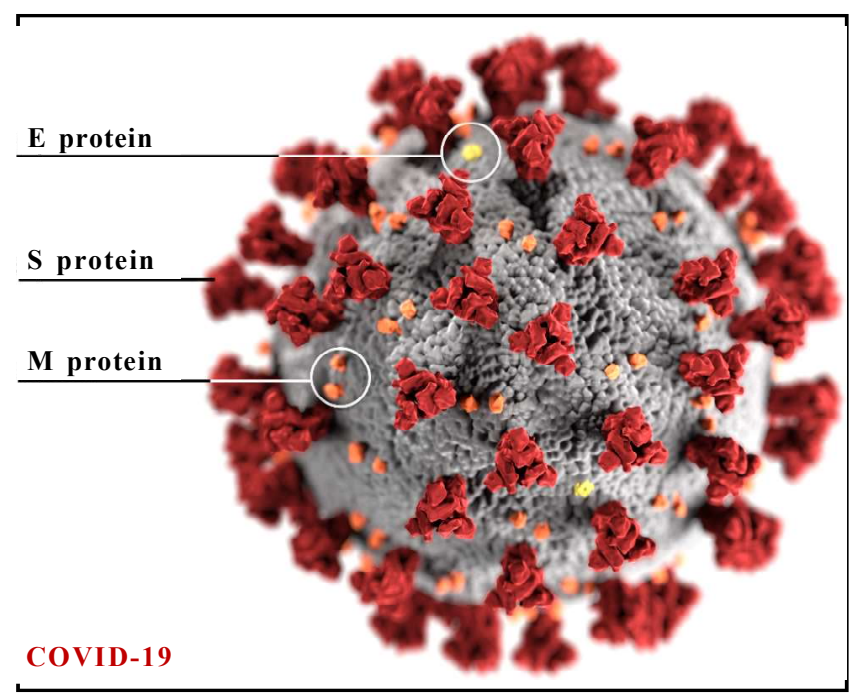

Corona virus - Photo credit: CDC/Alissa Eckert, MS; Dan Higgins, MAMS. (Source: Khan et al., 2020: The COVID-19 pandemic: A scoping review.)
The role of innate immunity against viral infections is crucial as the first line of defense. The pathogenicity followed by severity of symptoms and fatality is dependent on the ability of the virus to elude innate immune response. In case of COVID-19, acute respiratory distress syndrome (ARDS) was basically an outcome of dysregulated immune response or 'cytokine storm' due to secretion of pro-inflammatory cytokines (Cheng et al. 2020) and a moderate reduction in interferon (IFN) response during primary stage could be beneficial. Further, the innate immune response of fighting the virus is related to upregulation of interferon-stimulated genes (ISGs) such as IFIH1, ISG15, OAS1-3, MX1, IFITMs, etc. Simultaneously with an increased levels of proinflammatory cytokines like IL-6, IL-2 and IL1 $\beta$, tissue damage by the virus is increased. To date, we still are unclear of how the SARS-CoV-2 upsets the host innate immune response and aggravates to lead to severity of infection (Prasad et al., 2020).

Typically, the human body immediately elicits both innate as well as adaptive immune response against a viral infection. The preferred target for the SARS-CoV-2 are the ACE2 receptors. On entering the host cell, the virus releases its nucleic acid, i.e., RNA into the cell and the virus replicates (Cao et al., 2020). Thevarajan et al. (2020) investigated hospitalized patients with mild to moderate symptoms and observed an increase in activated $\mathrm{CD} 4^{+}, \mathrm{CD} 8^{+}$, follicular helper $\mathrm{T}$ cells and plasma B cells along with elevated levels of IgG and IgM. In contrast in patients with severe infection, a considerable fall in multiple immune cells as $\mathrm{B}, \mathrm{T}$ (both $\mathrm{CD}^{+}$as well as $\mathrm{CD} 8^{+}$) and NK cells, was observed alongwith lymphocytopenia. The neutrophil to lymphocyte ratio (NLR) as well as C-reactive protein levels, also significantly increased. It was further observed that in critically ill, pro-inflammatory cytokines along with chemokines, viz., TNF- $\alpha$, IL-2, 6, 7, 8, 10, monocytochemo attractant protein 1 (MCP1), GCSF, and macrophages were found to be elevated (Huang et al., 2020; Qin et al., 2020; Wang et al., 2020a). Elevated NLR, is an effective biomarker of systemic inflammatory response syndrome suggestive of high inflammatory response in the body. This is

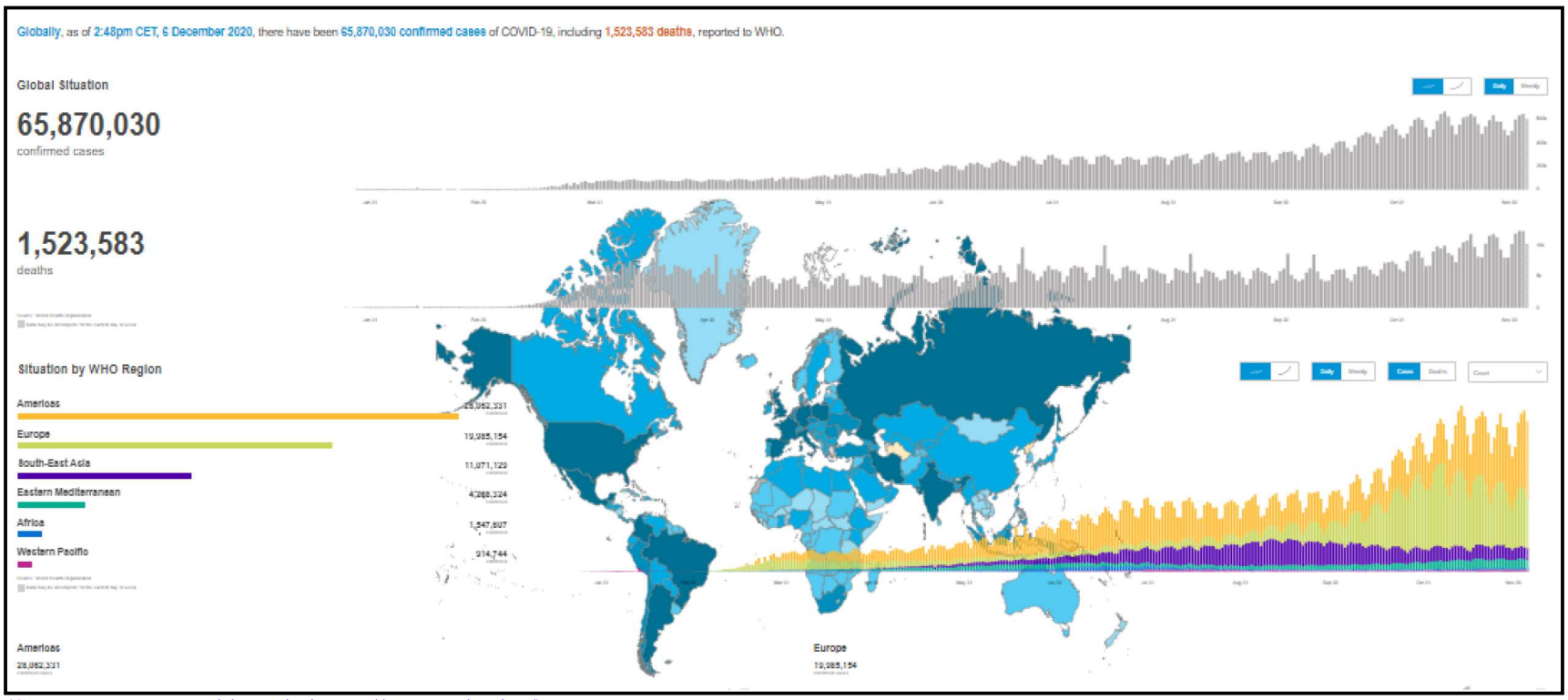

(Source: WHO Dashboard, https://www.who.int/) 
affected through the cytokine storm or uncontrolled release of cytokines and chemokines leading to over active inflammatory responses. Thus, the adaptive immune response is impaired becoming hyperactive and triggers multiple complications as viral sepsis, pulmonary injury leading to acute respiratory distress syndrome (ARDS) and ultimately to organ failure resulting in fatality (Prompetchara et al., 2020).

Since ancient times, across all cultures worldwide, plants have been used as alternative medicines for treatment of many acute as well as chronic infections (Salehi et al., 2019a; Sharifi-Rad et al., 2019; Salehi et al., 2020). In the last 25 years or so, researchers are emphatically making conscious efforts to substantiate potential of plants for health improvement (Sharifi-Rad et al., 2018). Ancient medicinal sciences as those from India, viz., Ayurveda, Siddhi and Unani or those from Chinese, Thai, Persian or Homeopathy, etc., are all being revisited in search for potent antiviral remedies (Yang et al., 2020). Ayurvedic science is a treasure with over 25,000 herbal formulations being used for various ailments, though lack of scientific research on their mechanism of action has hindered their acceptance to the world at large (Pundarikakshudu and Kanaki, 2019). Parasurman et al. (2014), rationalized that the medicinal plants contain multiple phytoconstituents which includes secondary metabolites as alkaloids, steroids, glycosides, tannins, terpenoids, saponins, etc., which are pharmacologically effective against various types of infections.

This compilation is aimed at reviewing the immunomodulatory effects of common medicinal plants, aromatic herbs, and spices that can prove beneficial against infections affecting the respiratory tract along with their role as antiviral. The readers can incorporate the usage of these food plants in their dietary regime for improving their overall health and keep them protected in this pandemic.

\section{Role of immunity boosters}

In current health crisis, efforts to understand the mechanism of natural products towards being antiviral through interruption of virus replication and its life cycle will help evolve a prophylactic along with a therapeutic modality. Ayush Ministry in India in its advisory published in 2020 suggests use of herbal plant products to strengthen immunity to enable one to fight infection. Enhancing the body's immune responses is one of the key factors impeding the virus attack. This will enrich the body's defense mechanism to mediate the desired immune responses as anti-inflammatory, intense cell mediated and regulated antigen presentation and also suppress activity of pro-inflammatory mediators along with proper coordination between the innate and cell mediated responses. The role of cytokines in the pathophysiology of SARS-CoV-2 is crucial as some of these like interleukin-7 and type-I interferon are beneficial while others as TNF- $\alpha$, interleukin- $1 \beta$ and 6 , appear to lead to cytokine storms which is detrimental. This escalation can be prevented through diet modulation by incorporating plant products with the potential of modulating the immune system along with appropriate sleep and a stress free environment (Jayawardena et al., 2020).

Calder et al. (2020) have revealed that the mediators of the immune system namely lymphocytes, helper T cells, natural killer cells along with secretions as antibodies and interleukins (IL4, 5, 10 and 13), get impaired in presence of stressors, alcoholic and carbonated beverages resulting in higher chances of infection and the transformation of lytic phase of virus into lysogenic one. These are also associated with the release of corticosols as epinephrine, norepinephrine and glucocorticoid which further weakens the immunity. The body's requirement for appropriate sleep to recoup its vitality is also an important facet associated with good immunity. Appropriate sleep boosts the immunogenic memory responses by assisting in $\mathrm{T}$ cell reorganization towards the lymph nodes. It also boosts immuno-surveillance as it increases count of natural killer cells, neutrophils, $\mathrm{T}$ cells and monocytes which thwart the detrimental health prevalence.

Increase in glucose intake or that of $\mathrm{CO}_{2}$ which is plentiful in beverages delays pathogen removal as it inhibits the activity of phagocytic macrophages. The recruitment of immune cells is increased with supplementation of micronutrients as vitamins. Good supplementation through natural vitamins enriches the immunomodulatory activities of many immune cells. Increase in the immune soldiers can prompt anticorona response. It is expected that these immune cells would activate the anti-coronavirus response through an increase in levels of secreted immunity mediators as secretion of antimicrobial peptides, defensin $\beta$ and cathelicidin along with activation of processes as chemotaxis, thereby leading to increased phagocytosis and neutrophil migration. This cascade further activates the $\mathrm{B}$ and $\mathrm{T}$ cell proliferation leading to more antibodies and cytokine synthesis helping curb the infection. The role of diet has been highlighted which can help in recouping from hypovitaminosis which is a fallout of infection (Khanna et al., 2020).

The role of minerals especially micronutrients in immunity is equally significant. These are abundant in the diet comprising of fruits and vegetables and the spices used in cooking. These fortify not only the innate but also the adaptive immune responses as they contain a variety of phytochemicals which facilitate better activity of immune cells. Thus, the role of a balanced diet to collaborate towards attaining optimal immunity is of utmost significance. Physical activities and regular exercises in open areas further assist the body's defense as sunlight is a potent virucide (Martin et al., 2009).

The active phytochemicals in the plant products also contribute to building strong immune responses. Innate immune response against viruses is given a boost by polyphenols as they form receptors which further increases their uptake leading to a signaling of innate immune responses. Nieman and Wentz, (2019) and Lin et al. (2017), depicted immune protective action against coronaviruses of much acclaimed resveratrol obtained from grape seeds. Another viable candidate is liquorice with glycyrrhizin as an active component which is known to possess anti-coronaviruses and SARS activity (Chen et al., 2004; Cinatl et al., 2003; Brush et al., 2006), and a potent candidate for trial drug for COVID-19. Well researched phytochemicals obtained from turmeric as curcumin and epigallocatechin gallate from tea are known to protect against allergies as well as grant immunity to gastrointestinal tract (GIT). 
Recently Khan et al. (2020), cited that plant based products have immense pharmacological potential and they can prove to be crucial resources for developing anti-COVID-19 therapeutic strategies. Figure 1 explains the potential of herbal products in enhancing and maintaining im munity against viral infections.

\section{Prospective herbal warriors}

A clear shift in the outlook towards healthy existence is being observed, as with advanced technology, life has become simple and at the same time the incidence of disorders associated with this life style as diabetes, hypertension, hyperlipidemia, etc., have increased. People are now seeking alternative and non-conventional therapies. The science of medicine has a strong foundation in India and Indian origin surgeon, Sushruta, is acclaimed across the world as father of surgery. The traditional Indian plant based therapies are acclaimed to have been one of the oldest health systems.

Multiple practices were followed through branches of Indian healing systems as ayurveda, yoga, siddha, and unani, along with homeopathy for curing various diseases and disorders (Gomathi et al., 2020). These various arms of therapy were founded using products from not only plants but even animals as well as minerals for treatment (Tabuti et al., 2003).

Not only in India, WHO suggests that close to $80 \%$ of world population has strong belief in the potential of herbal remedies. Thus, sincere efforts on part of researchers to provide scientific data to support the claim of such non-conventional therapies will go a long way in meeting global health.

\section{Medicinal plants and aromatic herbs}

4.1 Withania somnifera (L.) Dunal (Ashwagandha)

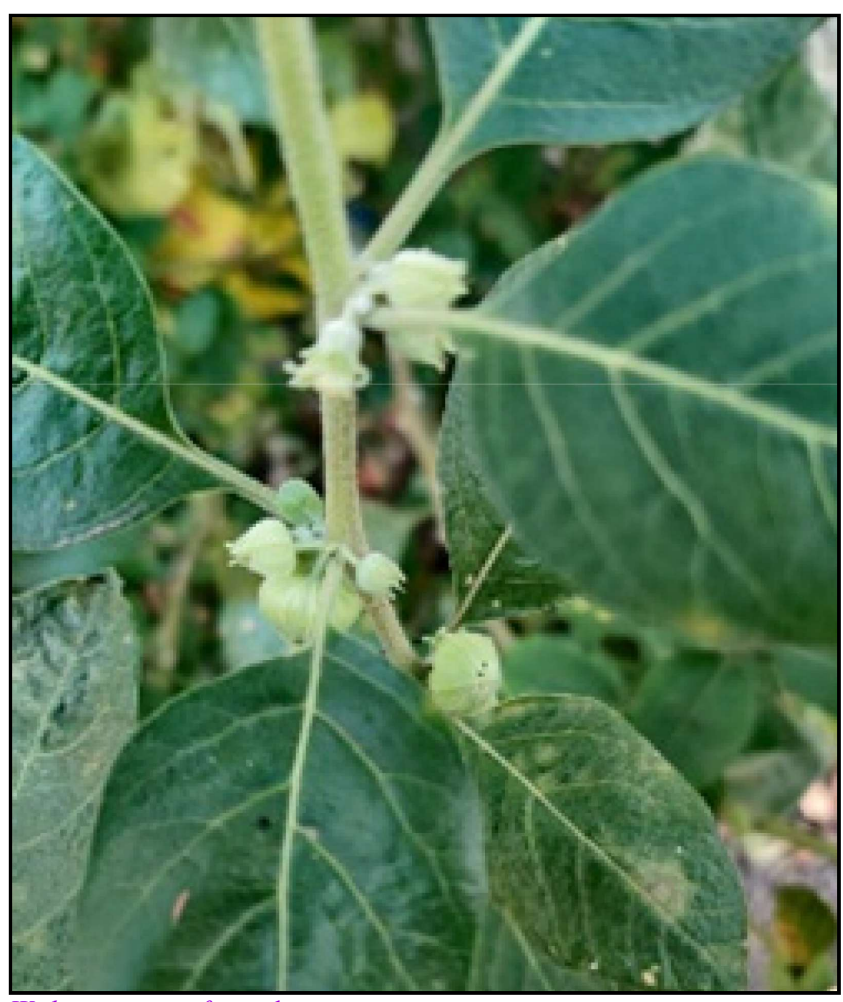

Withania somnifera plant.

(Source: Dr. Bindu Gopalkrishnan)

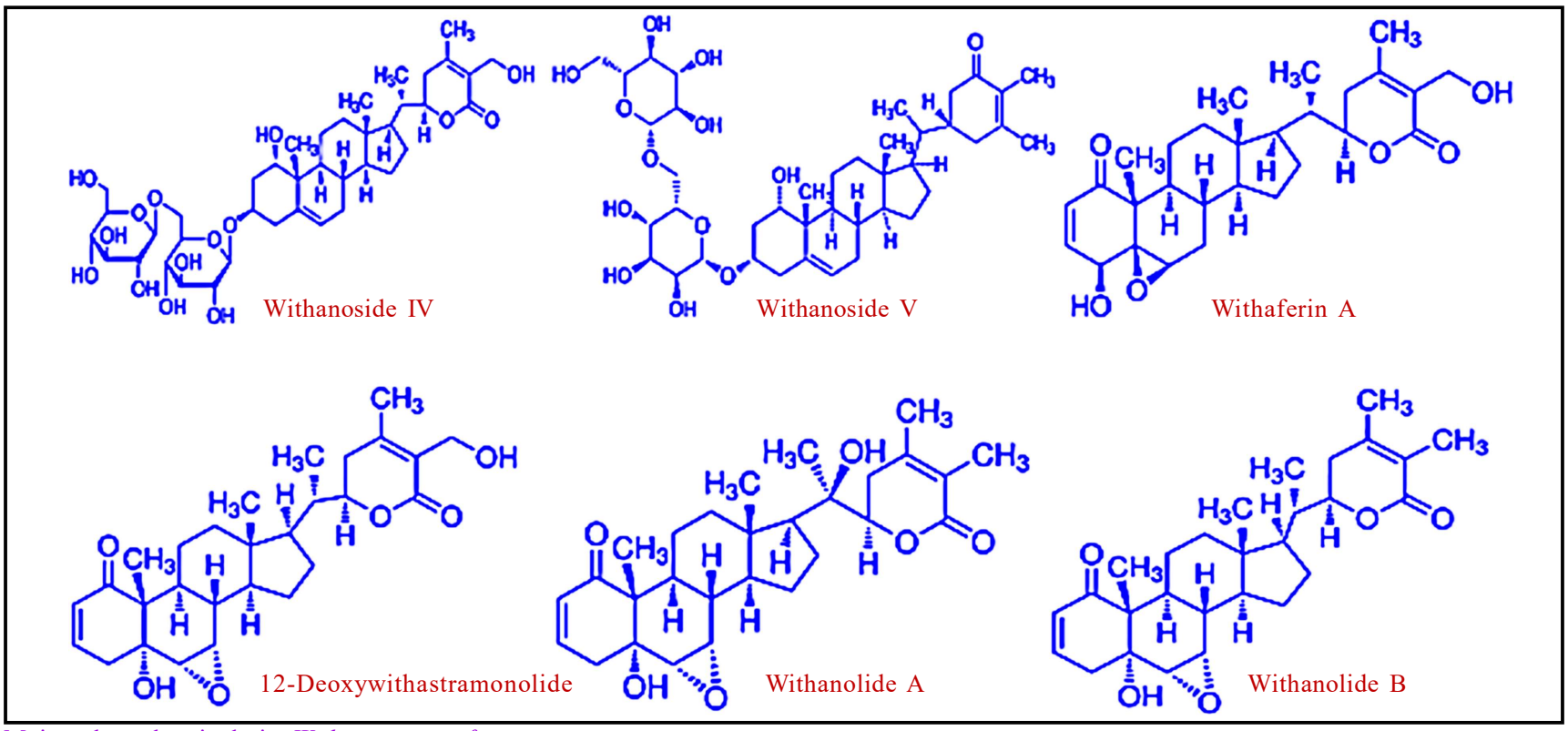

Major phytochemicals in Withania somnifera.

(Source: Nile et al., 2011)

Indian herb Withania somnifera (WS) (Ashwagandha) belongs to family Solanaceae and has been used as a traditional medicine by practitioners. Amongst the phytochemicals, the major ones are withaferins, steroid lactones, and steroid alkaloids of the withanolide series. (Nile et al., 2011). Chengappa, (2018) recorded that the plant acts as an immune booster while Sun et al. (2016) found the plant to possess anti-inflammatory activities. 
WS extract leads to enhanced phagocytotic activity by macrophages. Iuvone et al. (2003) reported that nitric oxide formation increased in presence of WS extract in a concentration dependent manner and resulted in further increase in macrophagal cytotoxic effect against pathogens and tumor cells. Nitric oxide synthase generates inflammatory mediators which inhibit pathogenic growth, and the secretion of this enzyme is increased in presence of WS extract. Other phytochemicals as glycosylated derivatives of withanolides, along with sito-indosides in a WS extract lead to activation of phagocytic activity as number of macrophages increases along with their mobilization. Rasool and Varalakshmi (2006) found the WS extract to possess effective inhibitory activity towards the mitogen induced lymphocyte proliferation, the complement system, and delayed-type hypersensitivity reaction. Vetvicka and Vetvickova, (2011) reported the ability of the herb to be used for its immunomodulatory, as well as rejuvenating and revitalizing properties. Jain et al. (2018) reported promising results with the phytochemicals in WS possessing antiinfluenza, antichikungunya, antibursal viral diseases as well as antiherpes simplex virus properties. Withaferin A (WA) is a potent antiviral against infectious bursal disease virus (IBDV) and HSV (Pant et al., 2012), HIV-1 (Shi et al., 2016) and HPV (Munagala et al., 2011). Thus, WS can prove to be a good immune booster by increasing the number of T, B as well as NK cells and modulating the Th-1/Th-2 immunity. The presence of antioxidants facilitates immune homeostasis. Further, it can help induce immunity against viruses by enhanced secretion of IFN- $\gamma$ responses.
A characteristic effect of coronavirus is the enhanced inflammation which too can be managed by WS extract, as it down regulates various cytokines as IL-1, IL-6, TNF $\alpha$ (Patwardan et al., 2020). Tripathia et al. (2020) reported that withanoside $\mathrm{V}$ is a potential inhibitor against $\mathrm{M}^{\text {pro }}$ of SARS-CoV-2 and could prove advantageous to combat COVID-19.

\subsection{Tinospora cordifolia (Willd.) Miers (Guduchi)}

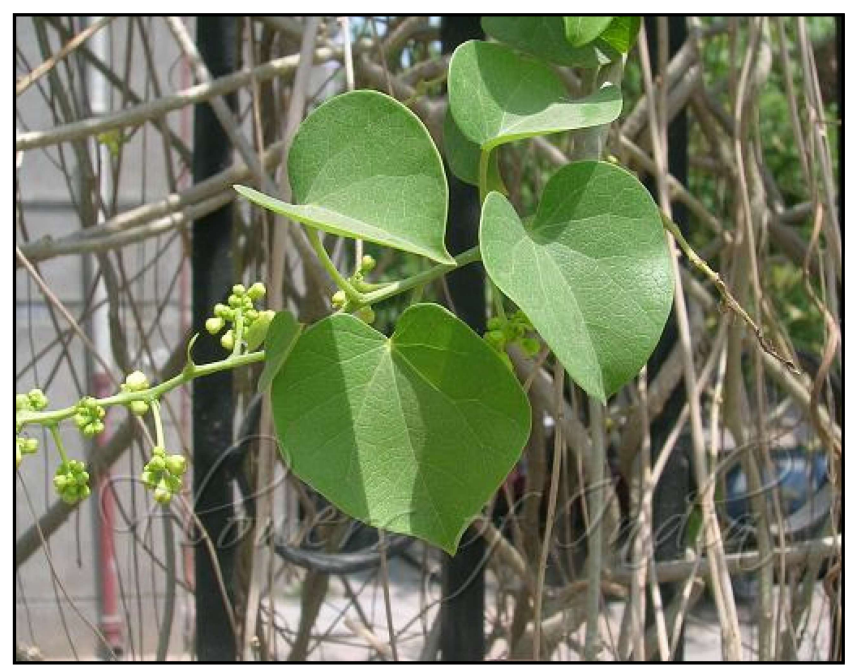

Tinospora cordifolia plant.

(Source: http://www.flowersofindia.net/extrapics/Gulbel-1.jpg)<smiles>C=C(C)CCOP(=O)([O-])OP(=O)([O-])O[Na]</smiles>

Major phytochemicals in Tinospora cordifolia.

(Source: Sharma et al., 2019)

Popularly termed 'Amrita' suggestive of its role in rejuvenating dead cells, Tinospora cordifolia (TC) is another popular herb known also for its immunomodulatory properties, facilitating enhancement of innate immunity against COVID-19 infections. The diterpenoid tinosporin, has antiviral potential and has proved to be effective for therapy of retroviruses and other viruses. The activation of immune cells along with cytokine production is influenced, post viral infection, by guduchi. The extract is rich in antioxidants and it increases the level of bioavailable Vit C which improve immunity (Akhtar 2010).
The proteins in the stem of the plant increase the phagocytic activity of macrophages and, thus it has immunomodulatory properties (Aranha, 2012). The extract of TC inhibits C3 convertase of the complement system, which is an anaphylatoxin, and it prevents release of proinflammatory anaphylactic peptides. Enhancement of IgG was also observed in a dose dependent manner (Kapil and Sharma 1997). 
Sagar and Kumar (2020) using in silico tools, tested the antiviral activity against targets used by the SARS-CoV-2 for host attachment and replication. The four targets used were the receptor domain $(6 \mathrm{M} 0 \mathrm{~J})$ and $6 \mathrm{VSB}$, the surface glycoprotein involved in attachment and the $6 \mathrm{M} 71$, which is an RNA dependent RNA polymerase and 6 Y84 - the protease responsible for viral replication. They suggested that the phytochemicals isocolumbin, berberine, tinocordiside and magnoflorine possessed high binding efficacy for all the targets studied, suggestive of the merits of this plant in management of COVID infection. Another similar study found strong stability of another protease 3CLpro for cardiofolioside B, tinosponone, berberine, xanosporic acid and tembetarine (Krupanidhi et al., 2020). Indian Government's Ayush Ministry (2020), in its health advisory have strongly recommended the use of $500 \mathrm{mg} \times 2$ tablets prepared using aqueous extract of TC as a preventive.

\subsection{Ocimum sanctum Linn. (Tulsi)}

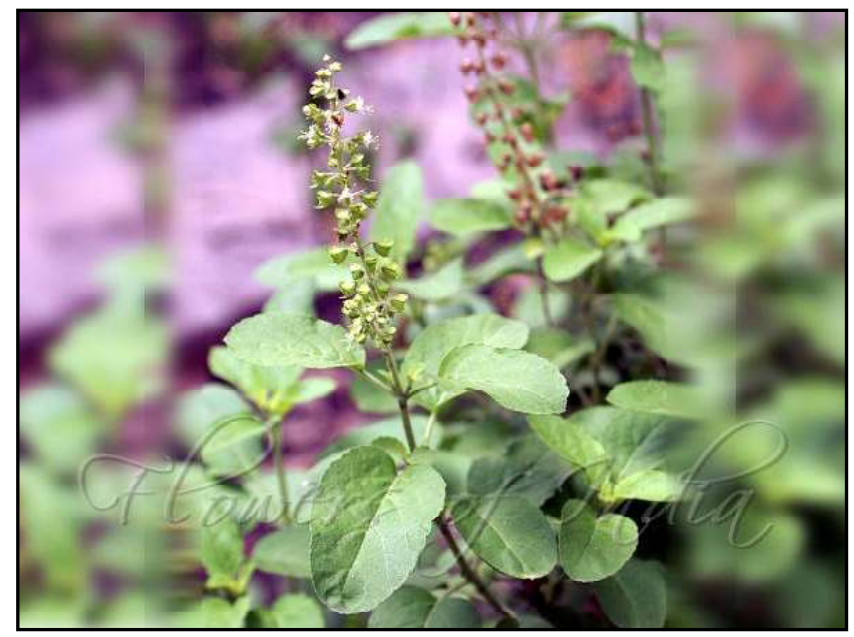

Ocimum sanctum plant

(Source: http://www.flowersofindia.net/catalog/slides/Tulsi.jpg)

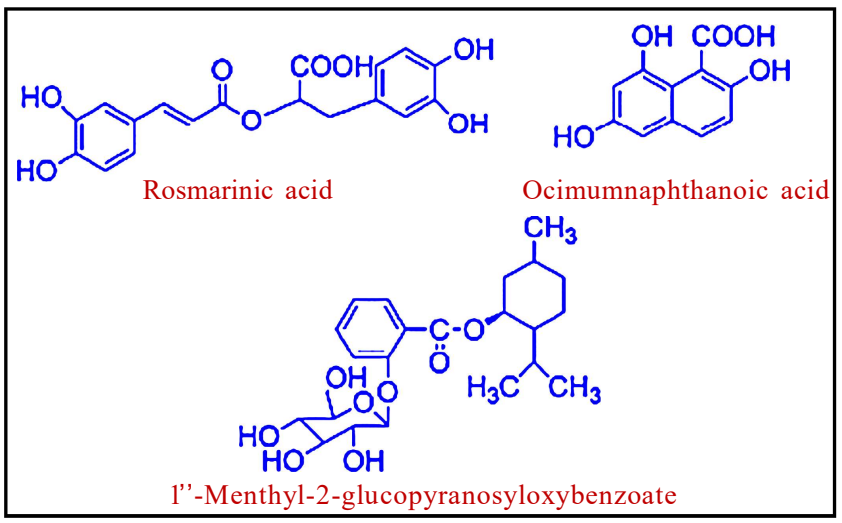

Major phytochemicals in Ocimum sanctum.

(Source: Singh and Chaudhuri, 2018)

Leaves of tulsi are considered pious and holy in India and it is a versatile herb with immense medicinal properties. For management of pain, fever, cough and cold as well as diarrhea, tulsi has been used since ancient times. One of the best remedies for pneumonia is tulsi along with cow ghee. This plant has proved as an antiviral for vaccinia virus, newcastle disease virus and infectious bursal disease virus (Prakash and Gupta, 2005). Beneficial effects of tulsi leaves decoction has been studied in respiratory disorders as cough and cold, bronchitis, asthma, and influenza and these were attributed to the phenolic content which provides antioxidant properties (Shivananjappa and Joshi, 2012).

An increase in NK and Th cell count and IL-4 secretion has been observed in presence of flavonoids from tulsi. Antiviral properties of the essential oil-eugenol have been found against hepatitis B virus, polio virus type 3 and herpes virus (HSV). An ethanolic extract was found to inhibit polio type 3 virus replication while ursolic and linalool acid depict broad-spectrum antiviral activity against DNA as well as RNA virus (Shrivastav and Saxena, 2020).

Ocimum sanctum seed oil (OSSO) showed immunomodulatory effect on both arms of adaptive immune responses, viz., humoral and cellmediated, which were associated with GABAergic pathways (Jeba et al., 2011). There was significant decrease in release of histamine and lymphokines due to inhibitory activity as well as leucocyte migration inhibition. It was suggested that it not only had a direct anti-inflammatory effect, but it also inhibited cell-mediated immune response. The leaf extract results in increase in phagocytic activity and increases the number of neutrophils and lymphocytes. Tulsi shows an increment in antibody production as well as the intermediaries of hypersensitivity reactions as the $\mathrm{WBC}$ count was increased along with an increase observed in haemagglutination titer (Mukherjee et al., 2005). These immunomodulatory properties can be credited to presence of flavonoids and terpenoids. Mediratta et al. (2002) reported that $O$. basilicum modulates both humoral and cell-mediated immune responses.

Shree et al. (2020) conducted in silico studies on 46 active phytochemicals found in $O$. sanctum (Tulsi) for affinity to the ligand N3 against SARS-CoV-2 Mpro. The phytochemicals exhibiting high affinity were Vicenin (CID_3084407), Isorientin 42-O-glucoside 23-Op-hydroxybenzoagte (CID_44257986,) and Ursolic acid (CID_64945).

\subsection{Aloevera (L.) Burm.f}

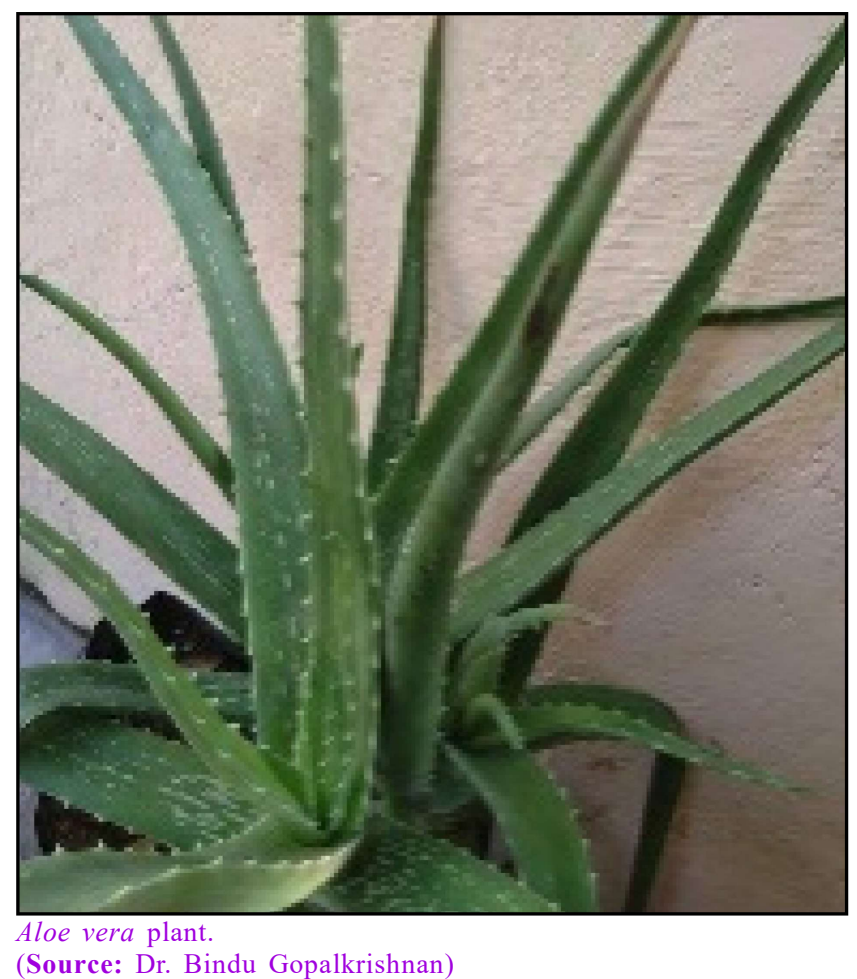




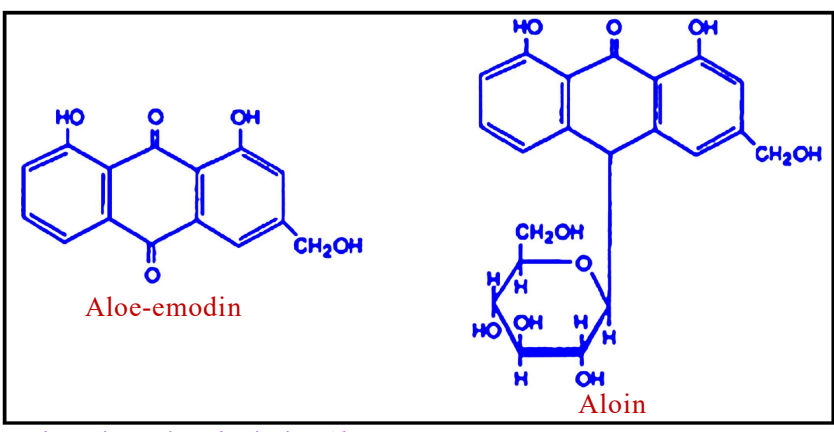

Major phytochemicals in Aloe vera.

Source: Shelton, 1991)

This 'miraculous or wonder plant' is known across various world cultures for its medicinal properties. The plant belongs to the family Xanthorrhoeaceae. The phytochemistry and pharmacology of this plant is well documented. The main polysaccharides present are glucomannan and acemannan and the other components are magnesium, calcium, zinc, vitamins A, C, E, plant sterols, cholesterol, carboxypeptidase, prostaglandin precursors as gammalinolenic acid, salicylic acid, lignins and saponins (Sharrif and Sandeep, 2011).

Aloe vera gels' main polysaccharide, acemannan is known to enhance the count of macrophages and T cells. The polysaccharide along with interferon gamma, facilitates macrophages to release NO and TNF- $\alpha$ which promotes phagocytosis, as the terminal mannose in acemannan is recognized as an antigen by macrophages due to it being similar in structure with polysaccharides present in microorganisms. In combination with interferon- $\gamma$, apoptosis was induced in the RAW 264.7 cell line (Tai-Nin Chow et al., 2005).

Acemannan upregulates the generation and function and cytotoxic T-cells and induces maturation of dendritic cells. Acemannan also has been found to possess antiviral activity in in vitro studies against HIV, influenza virus and newcastle disease, mainly by glycosylation of not only the glycoprotein coats of viruses but that of also virally infected cells (Sierra et al., 2014).

Termination of protein synthesis by the inhibition of nucleic acid biosynthesis was seen in herpes simplex virus type 1and 2 and in varicella-zoster virus (VZV) by aloe-emodin another component of the aloe gel (Pius et al., 2020a). Molecular docking studies to find the best ligand revealed that reactivity against the COVID-19 main protease (Mpro) was maximal for feralolide, followed by aloesin and aloeresin (Pius et al., 2020b).

\subsection{Allium sativum L. (Garlic)}

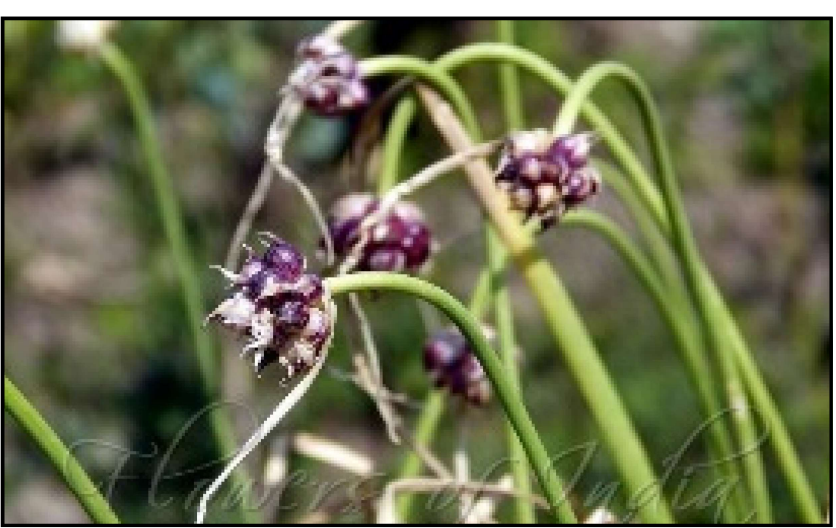

Allium sativum plant.

(Source: Picture credits: http://www.flowersofindia.net)

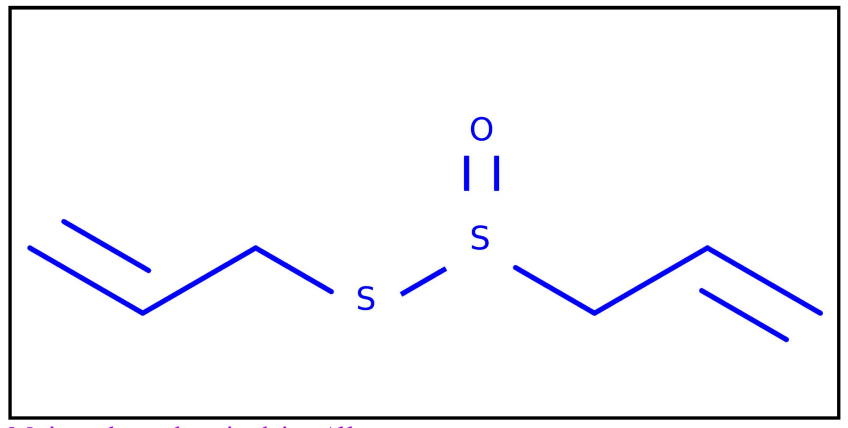

Major phytochemical in Allium sativum.

(Source: Borlinghaus, 2014)

Allium sativum has been documented to possess multiple medicinal properties since ancient times mainly due to it having good amount of organosulfur compounds and flavonoids. It contains anthocyanin, kaempferol, isorhamnetin and myricetin and organosulfur compounds like quercetin and allicin which is detrimental to the growth of many viruses (Kumar and Pandey, 2013).

Allicin mediates immunomodulatory effect by lymphocyte activation as thioallylation activates p21ras which stimulates phosphorylation of ERK1/2 (Borlinghaus et al., 2014)

The quercetins in garlic inhibits the replication of the virus transcription as RNA polymerase is inhibited due to increase in the uptake of zinc as well as the protein synthesis of the viral genome. Antiviral properties of quercetin derivatives have been documented against rhinovirus, poliovirus, influenza B, Ebola virus, hepatitis C virus, herpes simplex type 1 and 2, vaccinia virus, vesicular stomatitis virus and SARS-CoV which hinders virus attachment to host cell (Chen et al., 2006; Gruhlke et al., 2016) . Allicin, ajoene, methyl allyl thiosulfate and allyl methyl thiosulfinate help improve production of neutralizing antibodies. Amongst the most prominent constituents, allicin inhibits multiple thiol enzymes while ajoene helps prevents adhesive interaction of viruses and inhibits leukocytes.

The active components stimulate secretion of pro-inflammatory mediators like IFN $-\gamma$ and development of CD4 $+\mathrm{T}$ cells and macrophages. They also inhibit production of cyclooxygenase-2 and prostaglandin $\mathrm{E} 2$, via, NF- $\mathrm{KB}$ inactivation (Jeong et al., 2016). The anti-inflammatory effect can also be attributed to the signaling cascade activation in macrophages, direct suppression of toll-like receptor 4 (TLR4), lowering of nuclear

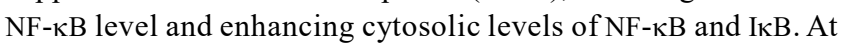
low doses garlic oil shifts adaptive immune response towards Th1-type and promotes development of anti-inflammatory response while at high doses the Th2 type is favored (Rodrigo et al., 2015).

Molecular docking analysis showed that alliin among other OSCs has higher antiviral potential to prevent COVID-19. This bioactive component alone or in combination with the main therapeutic drug would be an efficient therapy to eradicate SARS-CoV-2 with the lowest side effects and toxicity (Rajgopal et al., 2020). 
4.6 Zingiber officinale Roscoe (Ginger)

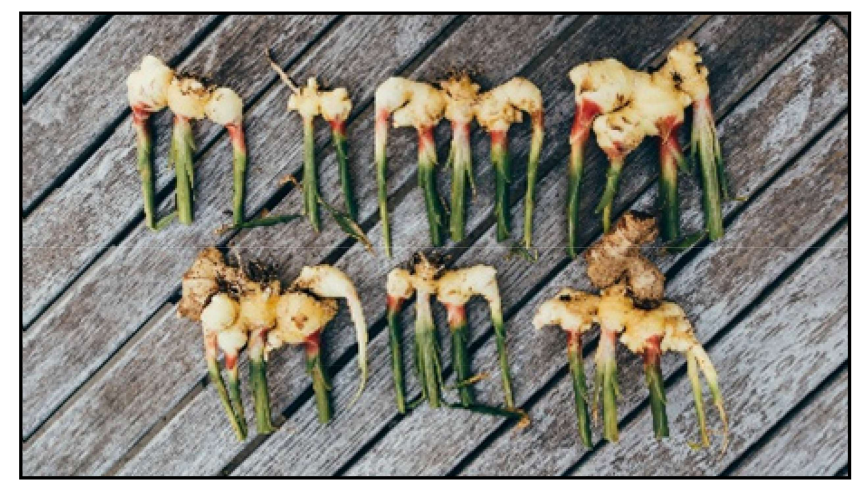

Zingiber officinale plant.

(Source: https://www.flickr.com/photos)

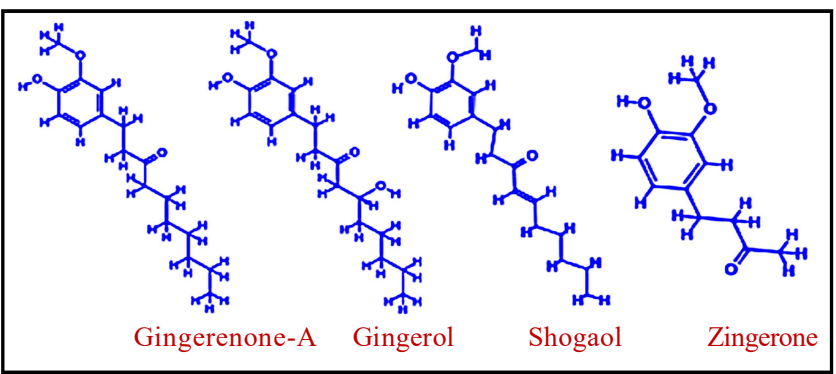

Major phytochemicals in Allium sativum

(Source: Rampogu et al., 2018)

Another common household remedy is ginger, rich in phenolic compounds as gingerols, shogaols, terpenes, raw fibers, organic acids, polysaccharides and lipids. It is known for its potential as an anti-inflammatory, antimicrobial, antioxidant, anticancer, cardiovascular, respiratory and neuroprotective, antidiabetic, antiobesity, antiemetic and antinauseatic (Mao et al., 2019).

The benefits of fresh ginger over dried one are more. The antiviral activity against human respiratory syncytial virus (HRSV) reduced significantly the plaque formation in presence of fresh ginger. It also inhibited viral attachment and internalization along with secretion of IFN- $\beta$ by mucosal cells (Abdel-Moneim et al., 2013). A similar effect is observed in management of common cold and fever which accompanies asthmatic conditions. Ginger has been recommended in liver disorders and as an antiviral. Viral replication inhibition against hepatitis $\mathrm{C}$ viral infection in infected Hep G2 cells lead to decrease in viral load and also in the levels of $\alpha$-fetoprotein levels as aspartate aminotransferace and alanine aminotransferase (El-Wahab et al., 2019).

It is used for therapy of GIT disorders as loss of appetite, constipation, flatulence, and digestive and malabsorption disorders. It showed promising results against feline calicivirus, a food borne disorder affecting alimentary channel (Aboubakar et al., 2016).

The active component allicin leads to secretion of cytokines like TNF- $\alpha$ having anti-influenza potential and leads to macrophage activation (Huang et al., 2006). It showed inhibitory activity against Herpes simplex virus type 2 (HSV-2) by inhibiting entry of virus by interacting with viral envelope (Koch et al., 2008).
In silico studies by Rajagopal et al. (2020) suggest that most potent components of ginger against COVID-19 Mpro inhibitor are 8 gingerol and 10 gingerol.

\subsection{Camellia sinensis (L.) Kuntze (Tea)}

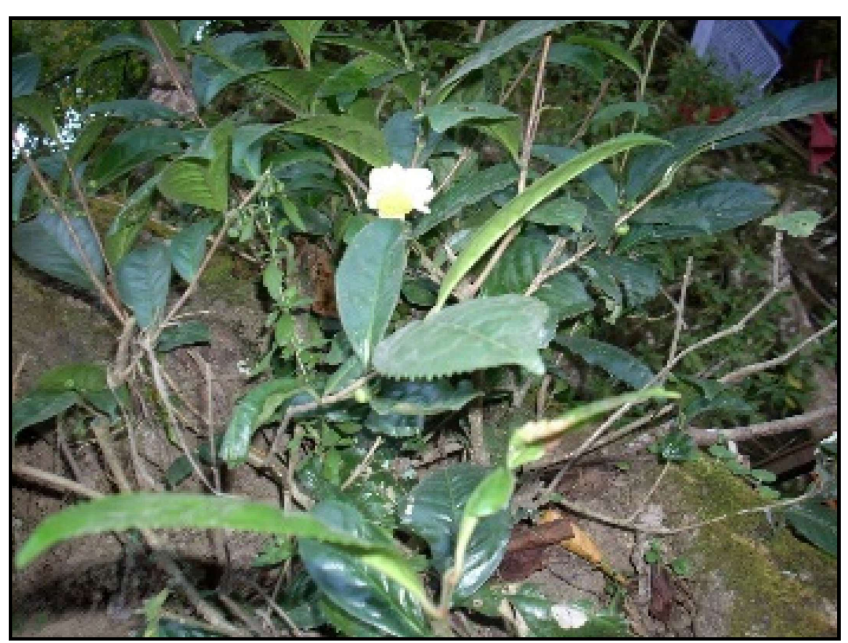

Camellia sinensis

(Source: Dr. Bindu Gopalkrishnan)

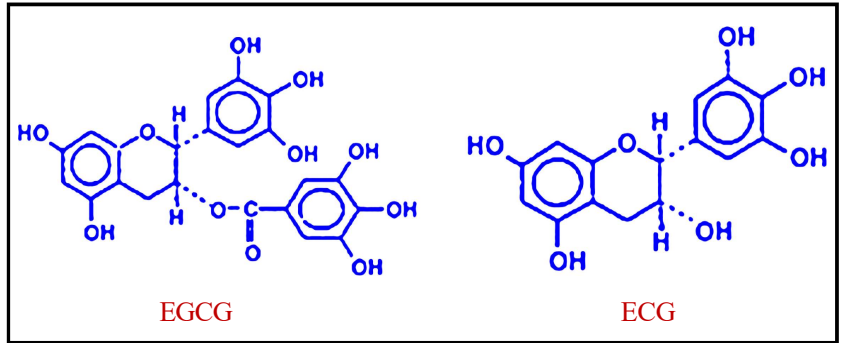

Major phytochemicals in Camellia sinensis.

(Source: Mahmood and Barkat, 2010)

The most consumed beverage in the world, tea is rich polyphenols with the most prominent being epigallocatechin gallate (EGCG) and theaflavin (TF), both depicting immunomodulatory competency. Other prominent phytochemicals present are tannins, flavonoids, caffeine, gallic acid, boheic acid, theobromine and theophylline (Mahmood and Barkat, 2010). As the plant is a perennial and acidophilic, it tends to accumulate micronutrients like selenium, copper, manganese, iron, and zinc from soil.

Tea is widely used for its multiple pharmacological benefits. The polyphenols act as antiviral for a wide range of both DNA and RNA viruses. The 3-galloyl and 5'-OH groups in EGCG lead to viral inhibitory activity (Kaihatsu, et al., 2018; Xu, et al., 2017). Micromolar concentrations of EGCG inhibits the infectivity of viruses as hepatitis $\mathrm{C}$ virus, human immunodeficiency virus, herpes simplex virus, influenza A virus, zika virus and dengue virus as it binds nonspecifically to viral surface proteins as this polyphenol competes with sialic acid and heparan sulphate for attachment of the virus onto host surface (Steinmann et al., 2013; Menegazzi et al., 2020) .

As for SARS-CoV-2, EGCG has been found to enhances secretion of interferon-type 1 and the activity of NK cells. It facilitates the regulation of NF-kB and RIG-I dependent signal transduction, 
inhibits the activity of ROS activity, apoptosis of neutrophils is regulated along with Th1/Th2 polarization. TF on the other hand down regulates NF-kB, ICAM-1, VCAM-and inhibits release of IL6, a proinflammatory cytokines (Chowdhury and Barooah, 2020). The micronutrients in tea further provide additional immunity against the cause of the current pandemic. Selenium acts as immunostimulatory regulating oxidative stress, macrophagic phagocytic activity, enhancing $T$, lymphocytes, leukocyte and NK cell proliferation and iron promotes activation of NF-kB cells and enhances host resistance to the intracellular pathogens. Zinc and copper plays a vital role in enhancing phagocyte activities as well as cytokine secretion by macrophages, works against reactive oxygen and nitrogen species and enhances the development and function of neutrophils and NK cells (Street et al., 2006).

Finally, Ghosh et al. (2020) have suggested that for the His41 and/or Cys 145 in the SARS-CoV-2 3CLPro catalytic pocket, EGCG and GCG displayed strong interaction and had potential as 3CLPro inhibitor.

\subsection{Emblica officinalis (Amla)}

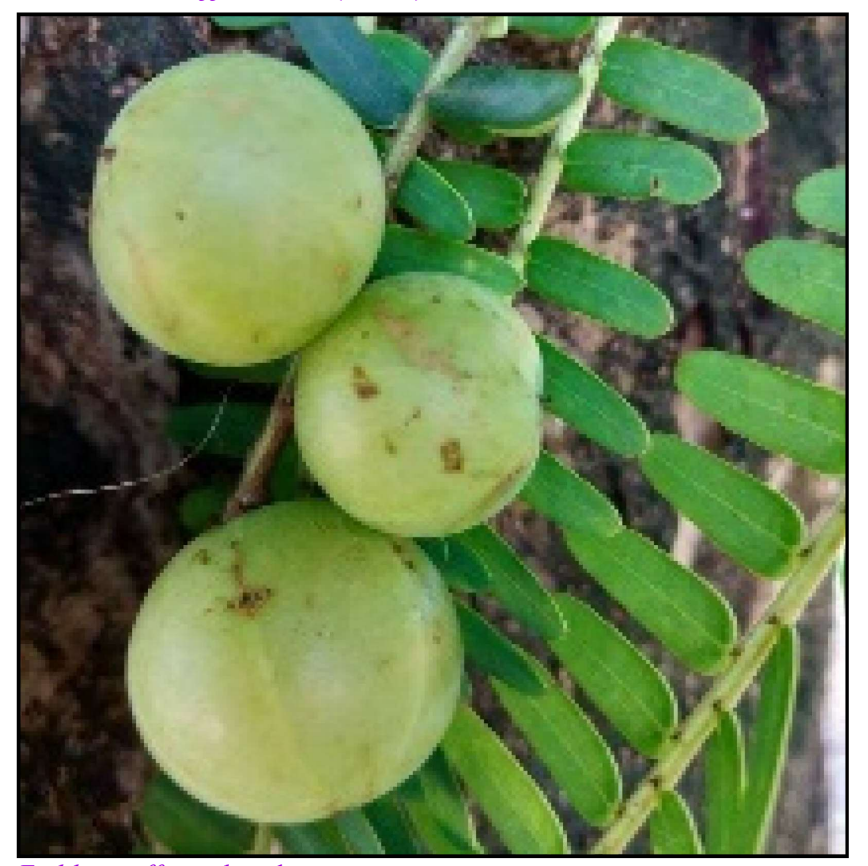

Emblica officinalis plant.

(Source: Dr. Bindu Gopalkrishnan)

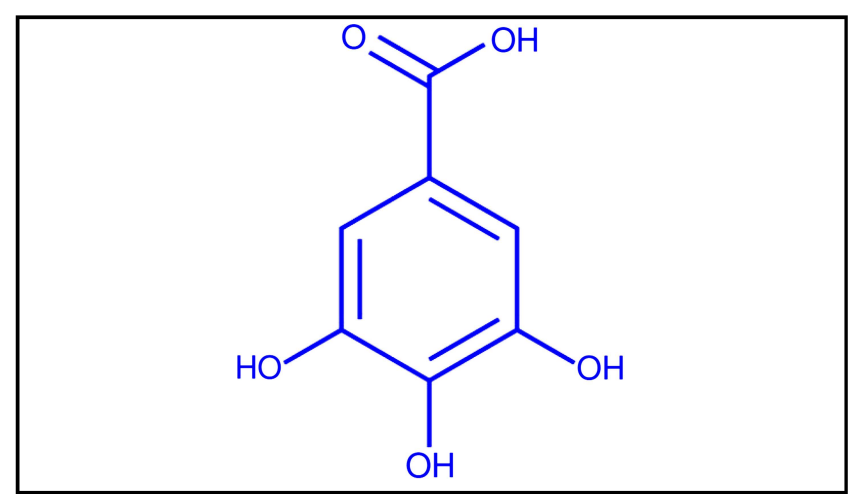

Major phytochemicals in Emblica officinalis.

(Source: Meena et al., 2010)
Emblica officinalis comes from the Euphorbiaceae family and is commonly called amla. Studies have shown amla to possess hepatoprotective, antitumor, anti-inflammatory and hypocholesterolemic activities. The fruit has considerably higher concentrations of most minerals, protein and amino acids like aspartic acid, glutamic acid, alanine, proline, cystine and lysine, gallic acid , furosin, $\beta$-glucogallin, corilagin, and geraniin. For a long time, it was believed that the amla fresh juice contains good quantity of vitamin $\mathrm{C}$, but it is now known that this activity is due to the emblicanin A, emblicanin B, pedunclagin and puningluconin which are hydrolysable tannins (Sai Ram et al., 2002).

Bhattacharya et al. (1999) have shown that amla extract significantly increases the antioxidant enzymes, viz., GPx, catalase, SOD, and reduced lipid peroxidation in the cortical and striatal concentration in the rat brain leading to reduction in free radicalinduced oxidative stress. Inhibition of retroviruses as HIV-1 and enhancement of immunity parameters have been attributed to the fruit extracts (El-Mekkawy et al., 1995). Sai Ram et al. (2002), demonstrated immunomodulatory and cytoprotective properties of amla along with chromium (Cr) which is believed to be an immunosuppressive agent. The antioxidant status was restored while free radical production was inhibited. Even the $\mathrm{Cr}$ associated immunosuppressive effects on lymphocyte proliferation were reversed along with the restoration of IL 2 and gamma IFN production. The activity of NK cell and antibody dependent cellular cytotoxicity was reinstated.

Singh et al. (2020) found the potential of using polyphenolic compounds as glucogallin found in amla on SARS-CoV-2, thereby preventing priming of the spike protein and post-translational modification of the viral protein. This polyphenol possessed good absorption and water solubility, no visible effect on essential drugs metabolism and liver enzymes inhibitory effects.

\subsection{Azadirachta indica A. Juss (syn. Melia azadirachta) (Neem)}

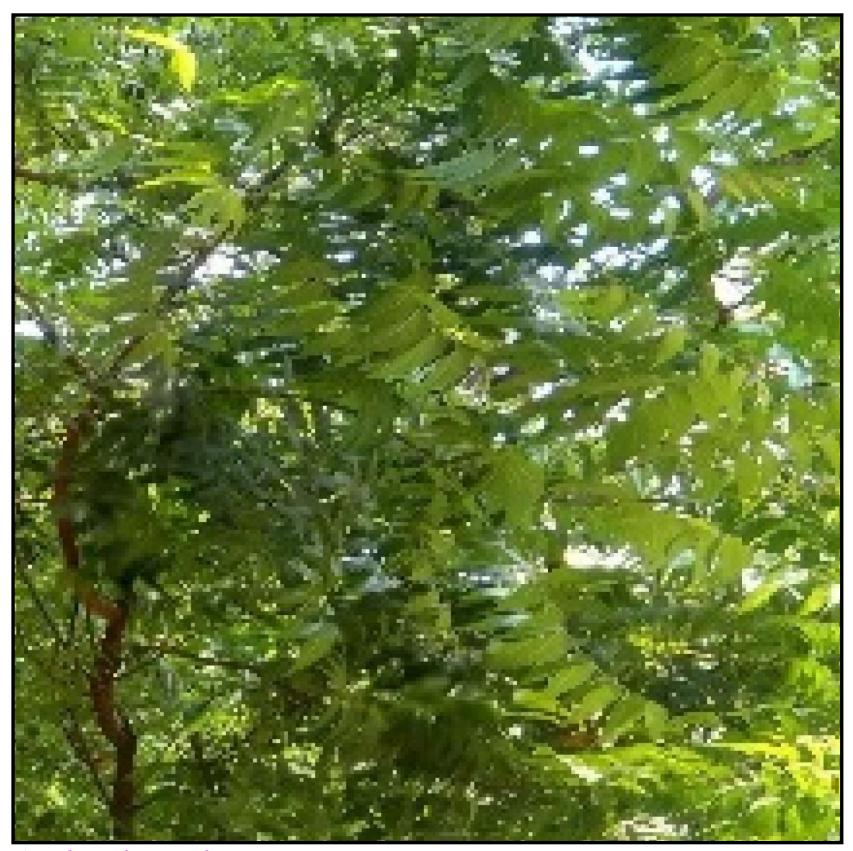

Azadirachta indica tree.

(Source: Dr. Bindu Gopalkrishnan) 


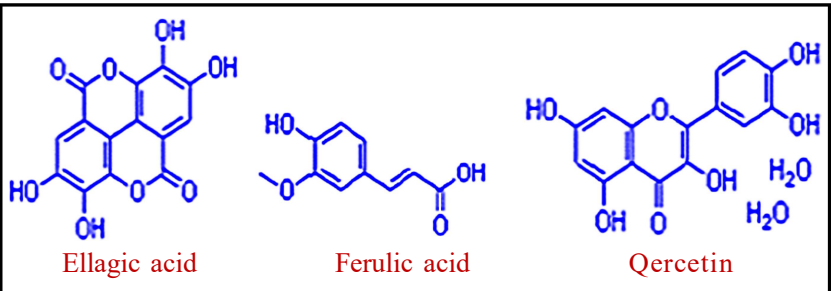

Major phytochemicals in Azadirachta indica.

(Source: Pandey et al., 2013)

Azadirachta indica or neem leaves and bark (family, Meliaceae) have been used across civilizations as one of the most versatile medicinal plants serving a wide spectrum of medicinal properties. The United Nations has denoted neem as 'the tree of the $21 \mathrm{st}$ century' for its multitherapeutic applications. It possesses antiinflammatory, antioxidant, antipyretic, immune modulatory, antiviral, anticancer, antibacterial and antifungal activities. Amongst the prominent compounds isolated from neem include nimbidin, nimbin, nimbolide, quercitin, $\beta$-sistosterol and limonoids. (Bhat et al., 2020; Pandey et al., 2013). It is a potent antiviral inhibiting viral replication in herpes simplex virus type-1, influenza strains coxsackieviruses, etc. (Tiwari et al., 2013).

The leaf extract of neem leaf has been used for treatment of especially fever and cough as per Ayurveda. Beneficial effects of neem leaf extract against dengue fever-related symptoms both in vivo and in vitro conditions were reported. Neem tree branch has potential to relieve cough and asthma (Biswas et al., 2002). Another symptom seen in few COVID-19 patients is diarrhoea and leaves of the plant can treat gastrointestinal disorder. The leaves, flower as well as bark extracts depict strong antioxidant potential and directly scavenge as well as prevent the hydroxyl radical mediated oxidative damage (Roy and Bhattacharyya, 2020).

Neem leaves extract induces both the arms of the adaptive immune response, i.e., humoral as well as cell-mediated response, as the glycoproteins present are effective in maintaining normal immune homeostasis through upregulation of type 1 responses as well as enhancing the antibody production against the infectious bursal disease and newcastle viruses (Bose et al., 2009; Zahid et al., 2013). Enhancement in immunity against HIV/AIDS patients through the increase in $\mathrm{CD}^{+}$cell count along with induction of dendritic cell maturation and macrophage, mediated antigen presentation has also been observed (Goswami et al., 2010).

The inhibitory effect on SARS-CoV-19, PLpro protein was noted for the phytochemicals from neem. Potential docking ability was reported, and good prospects were found in comparison with 7 drugs being currently tested against COVID-19, with desacetylgedunin (DCG), depicting the highest docking score. The influence of PLcpro and DCG docking, resulted from weak interactions as H-bonds, electrostatic and van der Waals forces and deformation of PLpro structure upon docking with DCG, thus proving its potential for drug development (Baildya et al., 2020).

\subsection{Glycyrrhiza glabra L. (Licorice/Mulethi)}

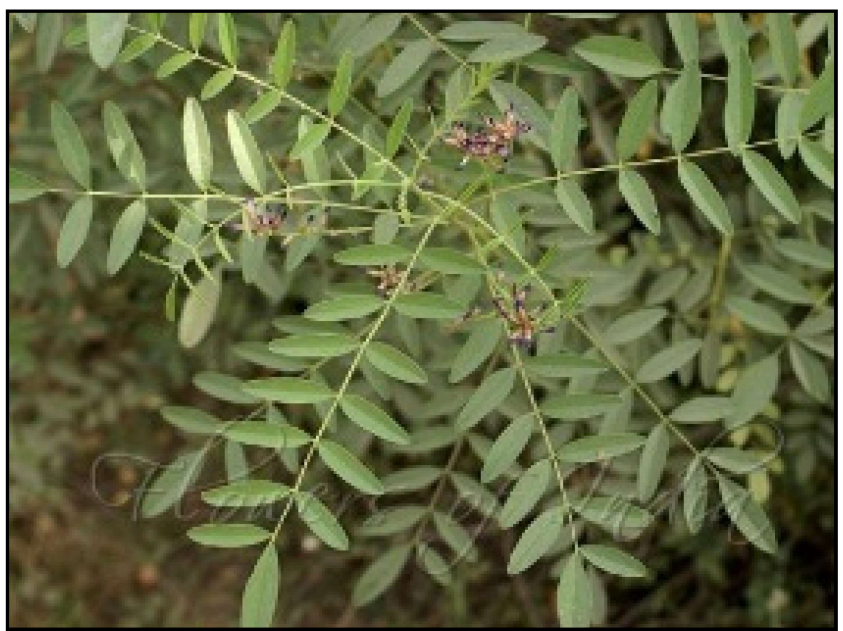

Glycyrrhiza glabra plant.

(Source: http://www.flowersofindia.net/extrapics/Licorice-1.jpg)

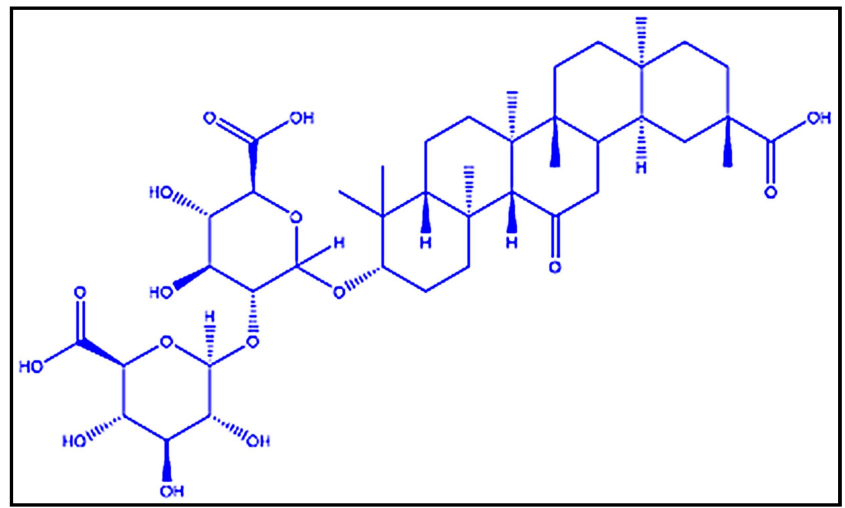

Major phytochemicals in Glycyrrhiza glabra.

(Source: Pastorino et al., 2018)

Glycyrrhiza glabra belonging to Fabaceae family is one of the most important medicinal plants from this family. Also termed licorice or mulethi, it is a native of Mediterranean areas, but present in Asia too. It holds a common remedy for cough, bronchitis gastrointestinal problems, and arthritis. It finds wide application for therapy of peptic ulcers, gastritis, and tremors. Unani folk medicine system asserts it to hold hot as well as wet temperament, as per their standard temperament scale. Its usage for respiratory ailments, due to it being a detoxicant, anti-inflammatory, antipyretic and immune empowering has been well studied. Recent scientific studies added to its foray of activities its potential as anti-microbial, anti-viral, antioxidant, immune modulating, anti-inflammatory and antitumor activities (Pastorino et al., 2018).

Nutritionally, it is rich in all biomolecules along with minerals as sodium, calcium, potassium, phosphorus, iron, selenium, zinc, magnesium, copper, silicon and manganese. Other phytochemicals present are glycyrrhizin, tannins, phytosterols namely sitosterol and stigmasterol, coumarins glabridin, 18-beta-glycyrrhetinic acid, liquiritigenin, licochalcone $\mathrm{A}$ and licochalcone $\mathrm{E}$, (Wang et al., 2015)

Antiviral property of glycyrrhiza and $18 \beta$ glycyrrhetinic acid extract was observed against human $\mathrm{H} 5 \mathrm{~N} 1$ and $\mathrm{H} 3 \mathrm{~N} 2$ influenza A virus, hepatitis C, coxackievirus B3 and A16, respiratory syncytial 
virus, and enterovirus. The extract adversely affects the adhesion of virus and gene expression affecting viral replication. The propagation of cellular response to inflammation due to degradation of IкB enzyme, activation of $\mathrm{T}$ lymphocyte proliferation, and suppression of host cell apoptosis has also been found to lead to antiviral activity of glycyrrhiza extract (Wang, 2015). Apoptosis of KSHV infected cells through down regulation in B-cells expression of latency was seen to be affected by glycyrrhizic acid (Damle, 2014). Cellular signaling pathways, via, nuclear factor $\kappa \mathrm{B}$, transcription factors, protein kinase $\mathrm{C}$, casein kinase II, and activator protein 1 were affected by glycyrrhizin. Up regulation of the expression of inducible nitric oxide synthase leading to production of nitric oxide in macrophage along with reduction in the expression of pro-inflammatory cytokines is also affected by glycyrrhizin and $18 \beta$ glycyrrhetinic acid (Cinatl et al., 2003).

\section{Spices}

\subsection{Curcuma longa L. (Turmeric)}

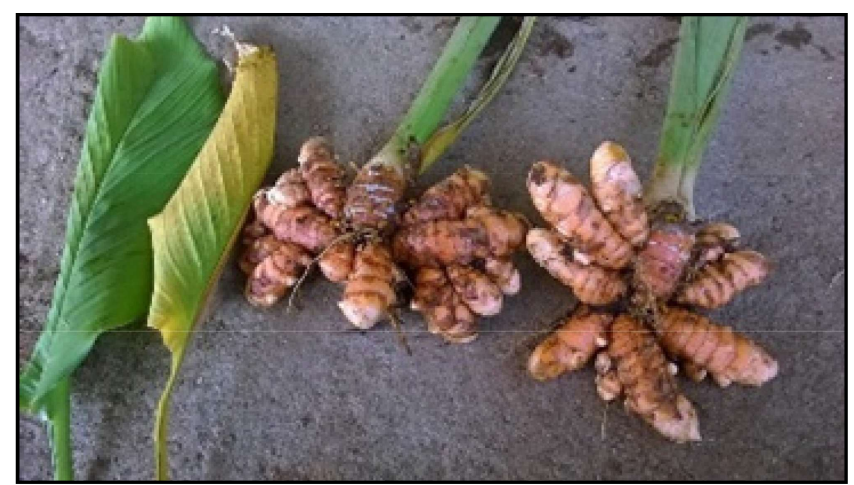

Curcuma longa plant.

(Source: Dr. Bindu Gopalkrishnan)

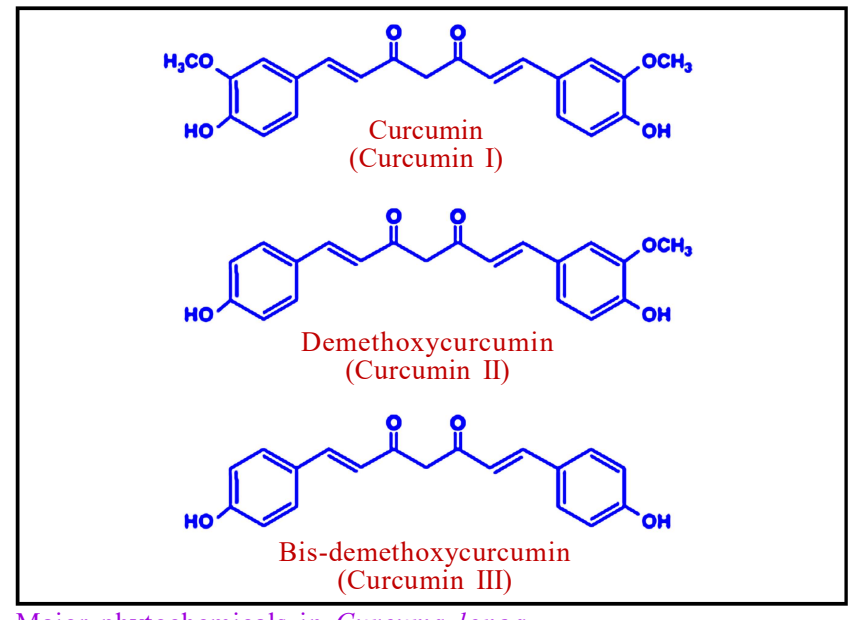

Major phytochemicals in Curcuma longa.

(Source: Popuri and Pagala, 2013)

'Indian saffron' or turmeric is bright yellow colored herb of the family, Zingiberaceae. Used as a flavoring agent across the Asian continent, it finds great application in ayurvedic science. The dried root is ground to powder and contains all proximate principles along with minerals and curcuminoids. The important ingredients in the plant are curcumin, dihydrocurcumin, and hexahydrocurcumin, along with volatile componds as cinol, borneol, zingiberine, $\alpha$-phellandrene, and many sesquiterpenes (Prasad and Aggarwal, 2011; Popuri, and Pagala, 2013)

Turmeric provides benefits for medical ailments as respiratory infections and curcumin, the most researched natural therapeutic nutrient, bestows preventive and curative effects in multiple disorders, infections, and malignancies (Soni et al., 2020). The immunomodulatory properties are due to interaction of curcumin with cells as B and T lymphocytes, dendritic cells, and macrophages. Curcumin and its derivative, namely; monoacetylcurcumin possess antiviral activity and have been shown to curtail infections of H1N1 and H5N1 influenza, hepatitis B and C, HIV, dengue, chikungunya and zika infections (Divya and Pillai, 2006). It enhances the boosting of $\mathrm{T}$ helper-1 mediated immune responses, by inhibiting $\mathrm{T}$ helper cytokine profile and suppressing interleukin-12 production by macrophages. Further, curcumin lowers the production of acute phase proteins thereby suppressing cortisol production (Si et al., 2007).

Curcumin impedes the spike protein, namely; ACE-2, furin, basigin, CatB/L and TMPRSS2, and also prevent entry of the virus in the host cells by inhibiting endosomal acidification. It further hampers the replication of SARS-CoV-2 by inhibiting RNA polymerase, MProthe main protease and also inhibits the release of virions. ACE inhibition leads to a decline in Ang II formation. The inactivation of Ang II is accelerated by enhanced expression of ACE2 by curcumin. Curcumin also downregulates angiotensin receptor inhibiting Ang II and this hampers NF- $\mathrm{kB}$ and MCP-1 activation. Formation of IL-6 and its receptor complex is also prevented as curcumin, which in turn inhibits the ADAM17, dodging adverse effects in COVID-19. Inhibition of STAT3 by curcumin, avoids inflammatory cytokines production. Experimentally supported evidences for the potential of curcumin in prophylactic management and therapy of respiratory infections lead to the recommendation of this spice for its antiCOVID advantage.

In silico studies predict curcumin direct binding with ligands inhibiting entry of virus into the host cells, as well as the modulation of correlated inflammatory events (Chen et al., 2020; Kandeel and Al-Nazawi, 2020; Maurya et al., 2020).

\subsection{Piper nigrum L. (Black pepper, Kaali mirch)}

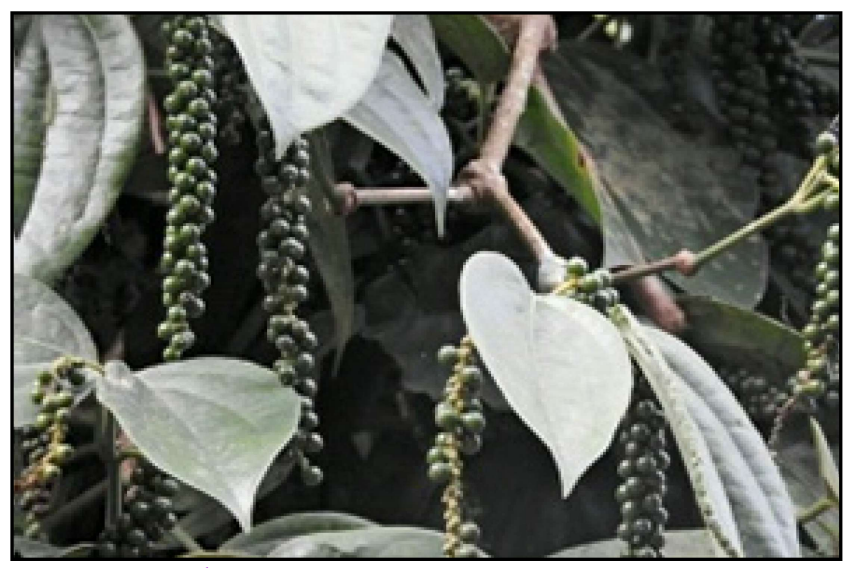

Piper nigrum plant.

(Source: Dr. Bindu Gopalkrishnan) 


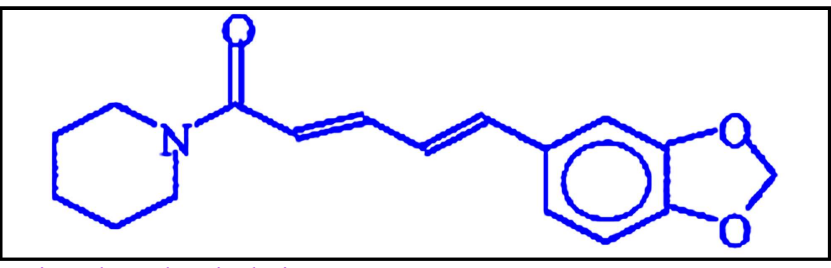

Major phytochemicals in Piper nigrum.

(Source: Raman and Gaikar, 2002)

Dried unripe fruit of Piper nigrum from family Piperaceae, is extensively used in most cuisines across the globe. An extract of black pepper is rich in phytochemicals, the main one being piperine, along with phenolics, alkaloids, flavonoids, steroids, amides, terpenes, lignans, neolignans, chalcones, etc., and their derivatives (Raman and Gaikar, 2002). Four isomers of piperine reported are piperine, isopiperine, chavicine and isochavicine. However, amongst all these compounds isolated, diverse pharmacological activities are seen in piperine, piperamide, pipene and piperamine. Pepper has been studied for its activities like antipyretic, analgesic, anti-inflammatory, antihypertensive, antiplatelets, antitumor, antiasthmatics, antidiarrheal, antispasmodic, antioxidant, antiviral, antibacterial, antifungal, hepatoprotective, immunomodulatory, anxiolytic, antidepressants, antithyroid, antimutagenic, antiapoptotic, antimetastatic and antispermatogenic (Damanhouri and Ahmad, 2014).

Pepper extract has been used to cater to therapy of viral infections in the respiratory tract, namely; coxsackie virus type B3 (CVB3), human rhinovirus type 2 (HRV2), and influenza virus type A(HK68) and, hence its use in fight against COVID-19 could be beneficial (Mair et al., 2016). Splenocytes proliferation is significantly enhanced by the aqueous extracts of black pepper in a dosedependent and cooperative manner, suggestive of promotion of proliferative signaling pathways in splenocytes. The release of the $\mathrm{Th}_{2}$ cytokines, namely; IL-4 and 10 are suppressed by black pepper while that of Th cytokine like IFN $\gamma$ is enhanced. Further, the aqueous black pepper extracts strengthen the NK cells cytotoxic activity (Majdalawieh and Carr, 2010).

Chaudhary et al. (2020) through docking studies have shown that piperine, has high binding affinity towards the RNA-binding pocket of the SARS-CoV-2 nucleocapsid and simulation confirmed it as a potential RNA-binding site inhibitor, suggestive that it is a potential candidate for drug development as it inhibits RNA packaging inhibiting the proliferation of virus.

\subsection{Trigonella foenum-graecum L. (Fenugreek/Methi)}

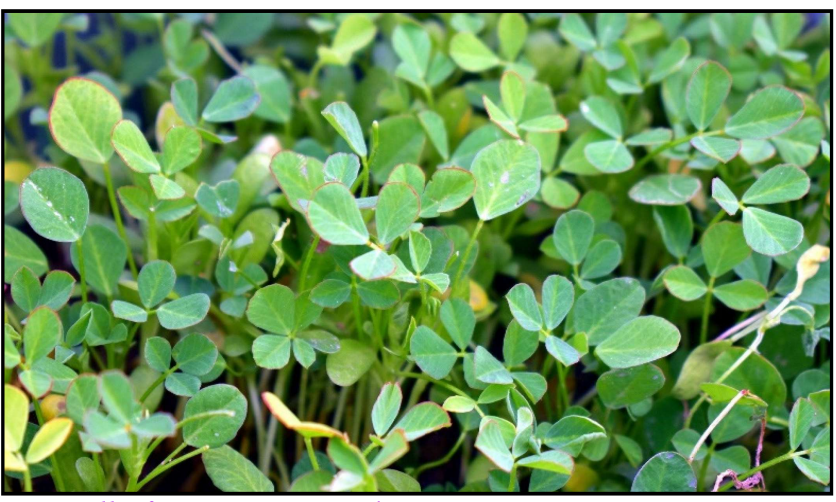

Trigonella foenum-graecum plant.

(Source: https://cdn.pixabay.com/photo/2017/11/20/11/39/fenugreek$2965214+340 . j p g)$

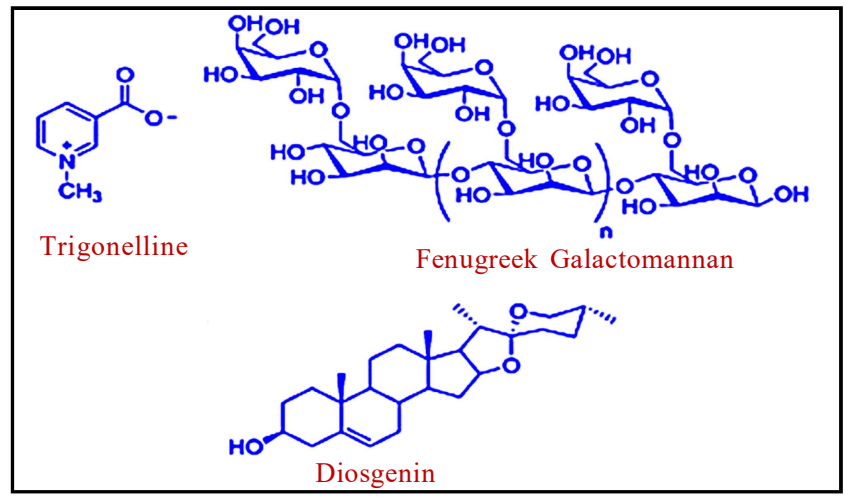

Major phytochemicals in Trigonella foenum-graecum. (Source: Venketa et al., 2017)

Fenugreek is member of family Fabaceae and is known as one of the oldest medicinal plant or spice with medicinal properties. Fenugreek seed contains $45-60 \%$ carbohydrates, mainly galactomannans-the mucilaginous fiber, proteins, lipids, alkaloids, mainly trigonelline and choline, polypenols as isovitexin and rhaponticin, saponins and minerals like calcium and iron (AbouShleel, 2014; Venketa et al., 2017). It has natural antioxidant properties and has found utility as food for strengthening the immune system. Its utility for relieving sore throat, colds, asthma, sinusitis, influenza, bronchial disorders, pleurisy, pneumonia, laryngitis, cataract, constipation, hay fever and tuberculosis, is well studied. It is also used a gastric stimulant, antidiabetic agent, antibacterial, hepatoprotective, galactagogue and anticancer (Srinivasan, 2006).

Fenugreek has been acclaimed for its immunomodulatory properties. The cellularity's of thymus and bone marrow along with that of spleen has been found to increase significantly in presence of fenugreek. At low doses, it increases delayed hypersensitivity responses. Plaque-forming cell (PFC) assay results indicative of humoral immunity showed an elevated response at high doses along with significant enhancement in phagocytic potential of macrophages (Rizwanul et al., 2003).

In silico studies with active ingredients in the spice, evaluated them as potential inhibitors of the main protease (Mpro) and spike (S) receptor of SARS-CoV-2, whose role is significant in entry of virus into host and the process of replication and transcription. Quercetin and luteolin from fenugreek are potent ligands for binding to main protease (Mpro) and spike (S) receptor of SARS-CoV-2, respectively (Sen et al., 2020).

\subsection{Nigella sativa L. (Black cumin)}

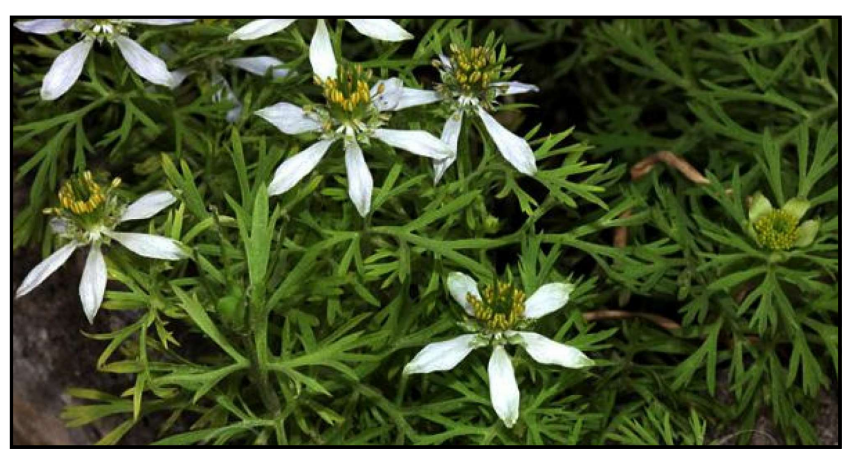

Nigella sativa L. plant.

(Source: Picture credits: http://www.flowersofindia.net/catalog/slides/ Black\%20Seed.jpg) 


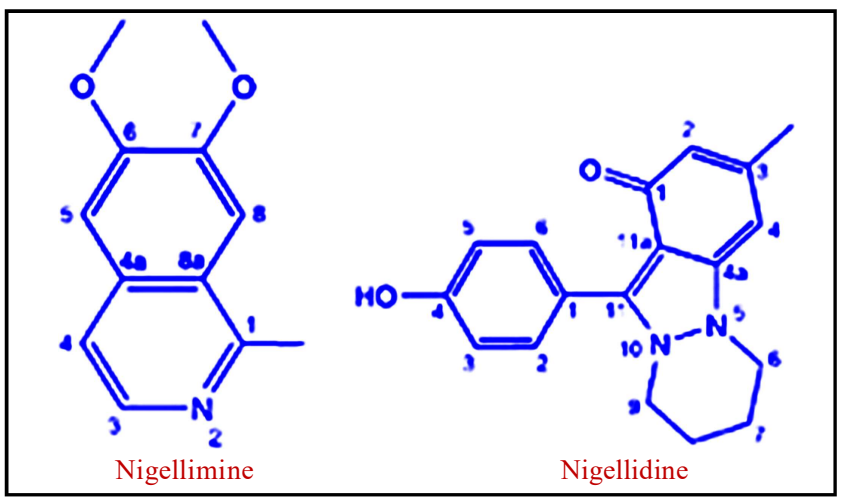

Major phytochemicals in Curcuma longa.

(Source: Popuri and Pagala, 2013)

Black cumin or Nigella sativa belongs to Ranunculaceae family, possessing a range of medicinal properties. The seeds as well as its oil has potential to treat asthma, inflammatory diseases, rheumatoid arthritis, diabetes and digestive diseases. The main properties in $N$. sativa are due to presence of thymoquinone, though other phytochemicals present are $\alpha$ and $\beta$-pinene, $p$-cymene, dithymoquinone (nigellone), carvacol, longifolene, pinene, thymo-hydroquinone, thymol, nigellidine nigelicine, and nigellimine, saponins and flavonoids (Muhammad et al., 2020).

Hossein et al. (2008) studied the arachidonic acid metabolism related enzymes against eosinophils and leukocytes suggestive of anti-inflammatory effect. Complexity arises in COVID-19 patients due to elevated pro-inflammatory cytokines like TNF $\alpha$ and IL-6 followed by lymphopenia associated acute respiratory distress syndrome. Inhibition of secretion of IL-6 is an effective treatment modality and thymoquinone inhibits not only IL- 6 but also IL-1, 10, 18 , along with TNF- $\alpha$, and NF- $\kappa B$, inducible nitric oxide synthase's and transforming growth factor (Srinivasan, 2018). Another active ingredient, $\alpha$-hederin interferes with secretion of IL-13, thereby suppressing the miRNA-126 expression (Muhammad, et al., 2020).

Docking studies suggest that thymoquinone, thymohydroquinone, nigelledine, hederagenin and $\alpha$-hederin, depict high to moderate affinity of binding with SARS-CoV-2 enzymes and proteins and carry potential to inhibit viral replication and host cell receptors attachment (Koshak and Koshak, 2020).

\subsection{Syzygium aromaticum (L.) Merr. and L.M. Perry (Clove)}

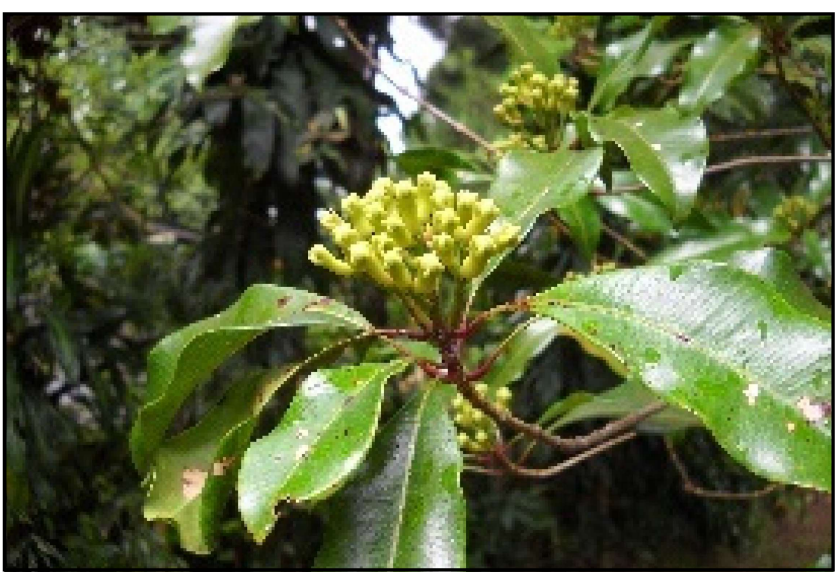

Syzygium aromaticum plant.

(Source: https://www.flickr.com/photos/ Clous de girofle)

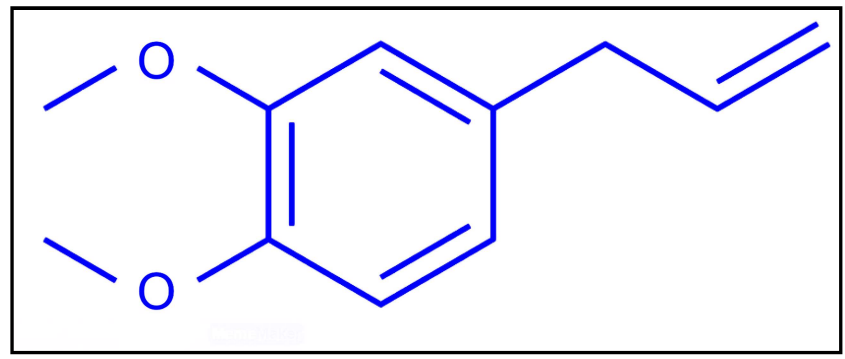

Phytochemical-Eugenol in Syzygium aromaticum. (Source: Mittal et al., 2014)

S. aromaticum, popularly referred as clove, is a dried flower bud from the Myrtaceae family. Reports document clove to possess antibacterial, antiviral, anti-inflammatory, analgesic, antipyretic, antioxidant and anticarcinogenic properties. It finds use for treatment of burns and wounds, tooth infections and toothache, flatulence, vomiting, liver-bowel and stomach disorders, nausea and nerve stimulant. It is used as appetizer, antipyretic, analgesic, anti-inflammatory decongestant, myorelaxant, antimicrobial, aphrodisiac, anxiolytic, hypnotic, antiemetic and antiepileptic.

Fresh plants are rich in eugenol-the major bioactive molecule, phenolic acids as ellagic, ferulic, caffeic, and salicylic acids, flavonoids as quercetin and kaempferol, gallic acid derivatives and tannins (Batiha et al., 2020; Mittal, et al., 2014).

Eugenol has proved to be antiviral against herpes simplex 1 and 2, as it prevents replication of the virus, thereby reducing chances of infection (Reichling et al., 2018). Cloves show suppression of $\mathrm{NF}-\kappa \mathrm{B}$ pathway, prevention of neutrophil and macrophage chemotaxis, inhibition of prostaglandin synthesis and the expression of cyclooxygenase II enzymes leading to antiinflammatory and immunomodulatory activities (Han and Parker, 2017). Eugenol also downregulates the pro-inflammatory cytokines namely IL-6 and TNF- $\alpha$ expression (Barboza et al., 2018).

\section{Conclusion}

Conquering COVID-19 is a worldwide challenge as this pandemic has bought not only people but the entire global economy on its toes. Currently, the preventive guidelines revolve around physical distancing, self-hygiene, and self-quarantine. The world of drug design and development is full of zeal towards early development of targeted drugs and a preventive vaccine, however, till the writing of this article, none of the products have hit market for commercial use. However, amongst this darkness, light prevails in use of herbal remedies which can be termed COVID warriors. Table 1 represents a summary of prospective warriors against COVID-19.

Comprehensive research directed towards herbal formulations, can provide lead in this battle. The key players in herbal products mediated therapy for SARS-CoV-2, is the presence of a large number of phytochemicals like aromatic oils, alkaloids, terpenoids, flavonoids, phenols, polyphenols, tannins and saponins, all known to possess innumerable antiviral properties. These aid in blocking not only virus particle invasion and penetration but are equally effective in averting its replication, expression, assembly and release. The key to overcoming the pandemic is working on developing immunity as depicted in Figure 1, for which these herbal defenders can play a vital role. This review on use of herbal 
remedies provides a repertoire of candidates which could be leads used for drug development through in silico studies. The natural herbal combatants in nature could be developed into frontline warriors in this battle against COVID-19 due to their potential to not only arrest viral growth in the body but also to develop a strong foundation of the immunity to combat infection.

Table 1: Prospective herbal remedies for COVID-19

\begin{tabular}{|c|c|c|c|c|}
\hline Medicinal plant & Common name & Phytochemicals & Antiviral action & References \\
\hline Withania somnifera & Ashwagandha & $\begin{array}{l}\text { Sito-indosides, } \\
\text { Withanolide-B, } \\
\text { Withanone and } \\
\text { Withaferin-A }\end{array}$ & $\begin{array}{l}\text { - Host Th1/Th-2 immune response modulation } \\
\text { - Upregulation of IFN-gamma responses } \\
\text { - Down-regulation of pre-inflammatory } \\
\text { mediators as IL-1, } 6 \text { and TNF- } \alpha\end{array}$ & $\begin{array}{l}\text { Patwardhan } \\
(2020) ; \\
\text { Maurya (2020) }\end{array}$ \\
\hline Tinospora cordifolia & Guduchi & $\begin{array}{l}\text { Alkaloid, terpenoids, } \\
\text { lignans }\end{array}$ & $\begin{array}{l}\text { - Increase the phagocytic activity of macrophages } \\
\text { - Inhibit release of proinflammatory } \\
\text { anaphylactic peptides } \\
\text { - Enhancement of IgG production }\end{array}$ & $\begin{array}{l}\text { Kapil and Sharma } \\
(1997) ; \\
\text { Aranha (2012) }\end{array}$ \\
\hline Ocimum sanctum & Tulsi & $\begin{array}{l}\text { Tulsinol (A, B, C, D, E, F, } \\
\text { G), dihydrodieuginol-B, } \\
\text { quercetin, eugenol, and } \\
\text { apigenin }\end{array}$ & $\begin{array}{l}\text { - Potential to inhibit SARs-CoV-2 } \mathrm{M}^{\text {pro }} \text { and } \\
\text { papain-like protease associated with viral } \\
\text { replication } \\
\text { - Upregulation of IFN } \gamma \text {, IL } 4, \mathrm{~T} \text { helper cells, } \\
\text { and NK cells }\end{array}$ & $\begin{array}{l}\text { Varshney et al. } \\
(2020) ; \\
\text { Goothy et al. } \\
(2020) \text {; } \\
\text { Mandal et al. }(2020)\end{array}$ \\
\hline Aloe Vera & Aloe vera & $\begin{array}{l}\text { Gammalinolenic acid, } \\
\text { salicylic acid, lignins and } \\
\text { saponins }\end{array}$ & $\begin{array}{l}\text { - Enhances macrophages and } \mathrm{T} \text { cells } \\
\text { - Upregulates the generation and function of } \\
\text { cytotoxic T-cells }\end{array}$ & $\begin{array}{l}\text { Tai-Nin Chow } \\
\text { et al. (2005) }\end{array}$ \\
\hline Allium sativum & Garlic & $\begin{array}{l}\text { Allicin, Alliin and S allyl } \\
\text { cysteine }\end{array}$ & $\begin{array}{l}\text { - Upregulation of IFN- } \alpha \\
\text { - Mitigates pulmonary fibrosis, lung injury, } \\
\text { and sepsis associated organ }\end{array}$ & $\begin{array}{l}\text { Bhattacharyya } \\
\text { et al. (2007) }\end{array}$ \\
\hline Zingiber officinale & Ginger & $\begin{array}{l}\text { Zingerone; and multiple } \\
\text { forms of gingerol }\end{array}$ & - Beneficial for pulmonary fibrosis and ARDS & $\begin{array}{l}\text { Kulkarni and } \\
\text { Deshpande }(2016)\end{array}$ \\
\hline Camellia sinensis & Tea & $\begin{array}{l}\text { Epigallocatechin gallate, } \\
\text { theaflavin and catechins }\end{array}$ & - Inhibition of 3C-like protease of SARS-CoV & Chen et al. [89] \\
\hline Emblica officinalis & Amla & $\begin{array}{l}\text { Phyllaemblicin-B and } \\
\text { phyllaemblinol, gallic acid, } \\
\text { furosin, } \beta \text {-glucogallin, } \\
\text { corilagin, and geraniin }\end{array}$ & $\begin{array}{l}\text { - High binding affinity against spike protein } \\
\text { and helicase protein, of COVID-19 } \\
\text { - Good antioxidative and anti-inflammatory } \\
\text { properties }\end{array}$ & Wu et al. (2020) \\
\hline Azadirachta indica & Neem & $\begin{array}{l}\text { Azadirachtin, Nimbolinin, } \\
\text { Nimbolide, Quercetin, and } \\
\beta \text { sitosterol }\end{array}$ & $\begin{array}{l}\text { - Reduction in macrophages and neutrophils } \\
\text { infiltration of preventing severe lung } \\
\text { damage }\end{array}$ & Lee et al. (2017) \\
\hline Glycyrrhiza glabra & Licorice/Mulethi & $\begin{array}{l}\text { Glycyrrhizin, tannins, } \\
\text { sitosterol and } \\
\text { stigmasterol }\end{array}$ & 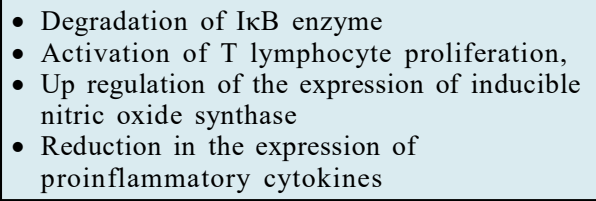 & $\begin{array}{l}\text { Cinatl et al. } \\
(2003) ; \\
\text { Wang, et al. } \\
(2015) ; \\
\text { Damle, (2014) }\end{array}$ \\
\hline Curcuma longa & Turmeric & $\begin{array}{l}\text { Curcumin, } \\
\text { Diacetylcurcumin and } \\
\text { Dedemethoxycurcumin, }\end{array}$ & $\begin{array}{l}\text { - Modification in structure and folding of } \\
\text { 3CL-protease } \\
\text { - Enhanced effectivity in comparison to } \\
\text { Nelfinavir, by diacetylcurcumin, } \\
\text { on COVID-19 (Mpro) }\end{array}$ & $\begin{array}{l}\text { Gonzalez et al. } \\
(2020) ; \\
\text { Adem et al. }(2020)\end{array}$ \\
\hline Piper Nigrum & $\begin{array}{l}\text { Black Pepper, } \\
\text { Kaali Mirch }\end{array}$ & $\begin{array}{l}\text { Piperine, alkaloids, flavonoids, } \\
\text { steroids, amides, terpenes, } \\
\text { lignans, neolignans, chalcones }\end{array}$ & $\begin{array}{l}\text { - Splenocytes proliferation } \\
\text { - Suppression of release of IL-4 and } 10 \\
\text { - Enhancement of IFN } \gamma\end{array}$ & $\begin{array}{l}\text { Majdalawieh and } \\
\text { Carr, }(2010)\end{array}$ \\
\hline $\begin{array}{l}\text { Trigonella foenum- } \\
\text { graecum }\end{array}$ & Fenugreek/Methi & $\begin{array}{l}\text { Trigonelline, choline, } \\
\text { isovitexin and rhaponticin }\end{array}$ & $\begin{array}{l}\text { - At low doses increases delayed hypersensitivity } \\
\text { - At high doses increases humoral immunity }\end{array}$ & $\begin{array}{l}\text { Rizwanul et al. } \\
(2003)\end{array}$ \\
\hline Nigella sativa & Black cumin & $\begin{array}{l}\alpha \text { and } \beta \text {-Pinene, } \\
\text { p-Cymene, Nigellone, } \\
\text { Nigellidine Nigelicine, and } \\
\text { Nigellimine, and } \\
\text { Thymo-hydroquinone }\end{array}$ & $\begin{array}{l}\text { - Inhibits IL- } 6, \mathrm{IL}-1,10,18, \mathrm{TNF}-\alpha \text {, and NF- } \mathrm{-B} \\
\text { - Induces nitric oxide synthase's and } \\
\text { transforming growth factor }\end{array}$ & $\begin{array}{l}\text { Rinivasan, et al. } \\
(2018)\end{array}$ \\
\hline Syzygium aromaticum & Clove & $\begin{array}{l}\text { Ellagic, ferulic, quercetin, } \\
\text { kaempferol, gallic acid } \\
\text { derivatives and tannins }\end{array}$ & $\begin{array}{l}\text { - Prevents virus replication } \\
\text { - Suppresses NF-kB pathway } \\
\text { - Prevention of neutrophil and macrophage } \\
\text { chemotaxis, Inhibition of prostaglandin } \\
\text { synthesis } \\
\text { - Downregulates the pro-inflammatory cytokines }\end{array}$ & $\begin{array}{l}\text { Barboza et al. } \\
(2018) ; \\
\text { Reichling et al. } \\
(2018) \text {; Han and } \\
\text { Parker, (2017) }\end{array}$ \\
\hline
\end{tabular}




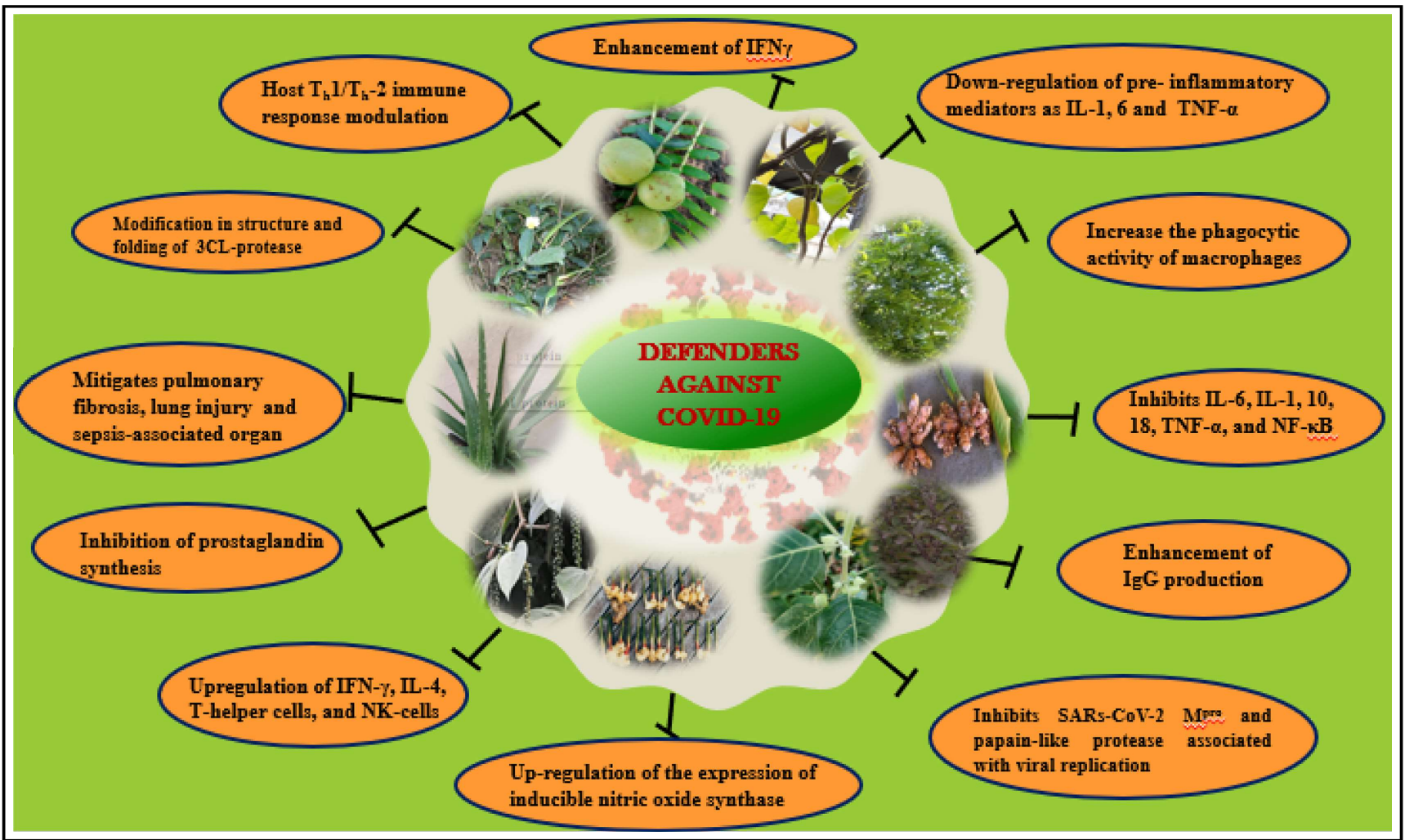

Figure 1: Immunoprotective action of medicinal plants, aromatic herbs and spices.

\section{Acknowledgements}

Financial and infrastructural support to the Department of Biochemistry from Shri Vile Parle Kelavani Mandal (SVKM) and Mithibai College (Autonomous) is gratefully acknowledged. I acknowledge the efforts of Dr. Bindu Gopalakrishnan (Department of Botany) for providing pictures of plants.

\section{Conflict of interest}

The author declares that there are no conflicts of interest relevant to this article.

\section{References}

Abdel-Moneim, A.; Morsy, B.M.; Mahmoud, A. M.; Abo-Seif, M. A. and Zanaty, M.I. (2013). Beneficial therapeutic effects of Nigella sativa and/or Zingiber officinale in HCV patients in Egypt. Excli J., 12:943-955

Aboubakar, H.A.; Nauertz, A.; Luong, N.T.; Agrawal, S.; El-Sohaimy, S.A.A.; Youssef, M.M. and Goyal, S.M. (2016). In vitro antiviral activity of clove and ginger aqueous extracts against feline calcivirus, a surrogate for human norovirus. J. Food Prot., 79(6):1001-1012.

Abou-Shleel, S. M. (2014). Effect of air temperature on growth, yield and active ingredients of Fenugreek (Trigonella foenumgraecum). Nature and Science, 12(9):111-115.

Adem, S.; Eyupoglu, V.; Sarfraz, I.; Rasul, A. and Ali, M. (2020). Identification of potent COVID-19 main protease (Mpro) inhibitors from natural polyphenols: An in silico strategy unveils a hope against corona. preprints, doi: 10.20944/preprints202003.0333.v1.
Ahmad, A.; Husain, A.; Mujeeb, M.; Khan, S.A.; Najmi, A.K.; Siddique, N.A.; Damanhouri, Z.A. and Anwar, F. (2013). A review on therapeutic potential of Nigella sativa: A miracle herb. Asian Pac. J. Trop. Biomed., 3:337-352. doi: 10.1016/S2221-1691(13)60075-1.

Akhtar, S. (2010). Use of Tinospora cordifolia in HIV infection. Indian Journal of Pharmacology, 42(1):57. https://doi.org/10.4103/02537613.62402

Aranha, I.; Clement, F. and Venkatesh, Y.P (2012). Immunostimulatory properties of the major protein from the stem of the Ayurvedic medicinal herb, guduchi (Tinospora cordifolia). Journal of Ethnopharmacology., 139(2):366-372. https://doi.org/10.1016/ j.jep. 2011.11 .013

Baildya, N.; Khan, A.A.; Ghosh, N.N.; Dutta, T. and Chattopadhyaya, A.P. (2020). Screening of potential drug from Azadirachta Indica (Neem) extracts for SARS-CoV-2: An insight from molecular docking and MD-simulation studies. J. Mol. Struct., 3:129390. doi: 10.1016/ j.molstruc.2020.129390.

Barboza, J.N.; da Silva Maia Bezerra Filho, C.; Silva, R.O.; Medeiros, J.V.R. and de Sousa, D.P. (2018). An overview on the anti-inflammatory potential and antioxidant profile of eugenol. Oxid. Med. Cell Longev., pp:3957262. https ://doi.org/10.1155/2018/39572 62

Batiha, G.E.S; Alkazmi, L.M.; Wase, L.G.; Beshbishy, A.M.; Nadwa, E.H. and Rashwan, E.K. (2020). Syzygium aromaticum L. (Myrtaceae): Traditional uses, bioactive chemical constituents, pharmacological and toxicological activities. Biomolecule, 10:202; doi:10.3390/ biom 10020202

Bhat, S.A., Rather, S.A.; Iqbal, A.; Qureshi, H.A. and Islam, A. (2020). Immunomodulators for curtailing COVID-19: A positive approach. Journal of Drug Delivery and Therapeutics, 10(3-s):286-294. 
Bhattacharya, A.; Chatterjee, A.; Ghosal, S. and Bhattacharya, S.K. (1999). Antioxidant activity of active tannoid principles of Emblica officinalis (Amla). Indian Journal of Experimental Biology, 37:676-680.

Bhattacharyya, M.; Girish, G.V.; Karmohapatra, S.K., Samad, S.A. and Sinha, A.K. (2007). Systemic production of IFN-alpha by garlic (Allium sativum) in humans. Journal of Interferon and Cytokine Research: The Official Journal of the International Society for Interferon and Cytokine Research, 27(5):377-382.

Bhushan Patwardhan; Preeti Chavan-Gautam; Manish Gautam; Girish Tillu; Arvind Chopra; Sunil Gairola and Suresh Jadhav (2020). Ayurveda rasayana in prophylaxis of COVID-19. Current Science, 118(8):1158-1160.

Biswas, K.; Chattopadhyay, I.; Banerjee, R.K. and Bandyopadhyay, U. (2002). Biological activities and medicinal properties of neem (Azadirachta indica). Current Science, Bangalore, 82(11):1336-1345.

Borlinghaus, J.; Albrecht, A.; Gruhlke, M.C.H.; Nwachukwu, I.D. and Slusarenko, A.J. (2014). Allicin: Chemistry and biological properties. Molecules, 19(8):12591-12618

Bose, A.; Chakraborty, K.; Sarkar, K.; Goswami, S.; Haque, E.; Chakraborty, T.; Ghosh, D.; Roy, S.; Laskar, S. and Baral, R. (2009). Neem leaf glycoprotein directs T-bet-associated type 1 immune commitment. Human Immunology, 70(1):6-15.

Brush, J.; Mendenhall, E.; Guggenheim, A.; Chan, T.; Connelly, E.; Soumyanath, A.; Buresh, R.; Barrett, R and Zwickey, H. (2006). The effect of Echinacea purpurea, Astragalus membranaceus and Glycyrrhiza glabra on CD69 expression and immune cell activation in humans. Phytotherapy Res.: Int. J. Devoted. Pharmacol. Toxicol. Eval. Natl. Prod. Derivatives, 20(8):687-695.

Calder, P.C.; Car, A.C.; Gombart, A.F. and Eggersdorfer, M. (2020) Optimal nutritional status for a well-functioning immune system is an important factor to protect against viral infections. Nutrients, 12:1181-1189.

Cao, X.; (2020). COVID-19: Immunopathology and its implications for therapy. Nat. Rev. Immunol. https://doi.org/10.1038/s41577-020-0308-3.

Chen, C.N.; Lin, C.P.; Huang, K.K.; Chen, W.C.; Hsieh, H.P.; Liang, P.H. and Hsu, J.T.A. (2005). Inhibition of SARS-CoV 3C-like protease activity by theaflavin-3, 30-digallate (TF3). Evid. Based. Complement. Alternat. Med., 2:209-215.

Chen, L.; Hu, C.; Hood, M.; Zhang, X.; Zhang, L.; Kan, J. and Du, J. (2020) A novel combination of vitamin $\mathrm{C}$, curcumin and glycyrrhizic acid potentially regulates immune and inflammatory response associated with coronavirus infections: A perspective from system biology analysis. Nutrients, 12(4):1193. https://doi.org/10.3390/ nu 12041193

Chen, L.; Li , J.; Luo, C.; Liu, H.; Xu, W. and Chen, G. (2006). Binding interaction of quercetin-3- $\beta$-galactoside and its synthetic derivatives with SARS-CoV 3CLpro: Structure-activity relationship studies reveal salient pharmacophore features. Bioorganic and Medicinal Chemistry, 14:8295-8306.

Cheng, Z.; Yu, T.; Xia, J.; Wei, Y.; Wu, W.; Xie, X.; Yin, W.; Li, H.; Liu, M. and Xiao, Y. (2020). Breadth of concomitant immune responses prior to patient recovery: A case report of non-severe COVID-19. Nat Med., 26(4):453-455. https://doi.org/10.1038/s41591-020-0819-2.

Chengappa, K.N.R.; Brar, J.S.; Gannon, J.M. and Schlicht, P.J. (2018). Adjunctive use of a standardized extract of Withania somnifera (Ashwagandha) to treat symptom exacerbation in schizophrenia: A randomized, double-blind, placebo-controlled study. J. Clin. Psychiatry; 79(5):17m11826. doi: $10.4088 / \mathrm{JCP} .17 \mathrm{~m} 11826$.
Choudhary, P.; Chakdar, H.; Singh, D.; Selvaraj, C.; Singh, S.K.; Kumar, S. and Saxena, A.K. (2020). Computational studies reveal piperine, the predominant oleoresin of black pepper (Piper nigrum) as a potential inhibitor of SARS-CoV-2 (COVID-19). Current Science (00113891), 119(8):1333-1342.

Chowdhury, P. and Barooah, A.K. (2020). Tea bioactive modulate innate immunity: In perception to COVID-19 pandemic. Frontiers in Immunology, doi: 10.3389/fimmu.2020.590716.

Cinatl, J.; Morgenstern, B.; Bauer, G.; Chandra, P.; Rabenau, H. and Doerr, H.W. (2003). Glycyrrhizin, an active component of liquorice roots, and replication of SARS-associated coronavirus. Lancet, 361(9374): 2045-2046.

Cui, J.; Li, F. and Shi, Z. L. (2019). Origin and evolution of pathogenic coronaviruses. Nature Reviews. Microbiology, 17:181-192.

Damanhouri, Z.A. and Ahmad. A. (2014). A review on therapeutic potential of Piper nigrum L. (Black Pepper): The king of spices. Med. Aromat. Plants, 3(3):http://dx.doi.org/10.4172/2167-0412.1000161

Damle, M. (2014). Glycyrrhiza glabra (liquorice): A potent medicinal herb. International Journal of Herbal Medicine, 2(2):132-136.

Divya, C.S. and Pillai, M.R. (2006). Antitumor action of curcumin in human papillomavirus associated cells involves downregulation of viral oncogenes, prevention of NFkB and AP-1 translocation and modulation of apoptosis. Molecular Carcinogenesis, 45(5):320-332.

El-Mekkawy, S.; Meselhy, M.R.; Kusumoto, I.T.; Kadota, S.; Hattori, M. and Namba, T. (1995). Inhibitory effects of Egyptian folk medicines on human immunodeficiency virus (HIV) reverse transcriptase. Chemical Pharmocology Bulletin, 43:641-648.

EI-Wahab, A.A.; El-Adawi, H. and El-Demellawy, M. (2012). In vitro study of the antiviral activity of Zingiber officinale. Ethnopharmacology, 139(2):366-372.

Gao, H.; Guo, L.; Xie, J.; Wang, G.; Jiang, R.; Gao, Z.; Jin, Q.; Wang, J.; Cao, B. (2020). Clinical features of patients infected with 2019 novel coronavirus in Wuhan, China. Lancet, 395(10223):497-506.

Ghosh, R.; Chakraborty, A.; Biswas, A. and Chowdhuri, S. (2020). Evaluation of green tea polyphenols as novel corona virus (SARS CoV-2) main protease (Mpro) inhibitors: An in silico docking and molecular dynamics simulation study. J. Biomol. Struct. Dyn., pp:1-13. doi: 10.1080/07391102.2020.1779818

Gomathi, M.; Padmapriya, S. and Balachandar, V. (2020). Drug studies on rett syndrome: From bench to bedside. J. Autism Dev. Disord., pp:1-25. https://doi.org/10.1007/s10803-020-04381-y.

Gonzalez-Paz, L.A.; Lossada, C.A. and Moncayo, L.S. (2020). Theoretical molecular docking study of the structural disruption of the viral 3CL-protease of COVID19 Induced by binding of capsaicin, piperine and curcumin Part 1: A comparative study with chloroquine and hydrochloroquine two anti-malaric drugs. Research Square, doi: $10.21203 /$ rs.3.rs-21206/v1.

Goothy, S.; Goothy, S.; Choudhary, A.; Potey, G.; Chakraborty, H. and Kumar, A. (2020). Ayurveda's holistic lifestyle approach for the management of coronavirus disease (COVID-19): Possible role of tulsi. International Journal of Research in Pharmaceutical Sciences, 11(3): 16-18

Goothy, S.S.K.; Goothy, S.; Choudhary, A.; Potey, G.G.; Chakraborty, H.; Kumar, H.S. and Mahadik, V.K. (2020). Ayurveda's holistic lifestyle approach for the management of coronavirus disease (COVID-19): Possible role of tulsi. Int. J. Res. Pharm. Sci., 11(1):16-18. 
Goswami, S.; Bose, A.; Sarkar, K.; Roy, S.; Chakraborty, T.; Sanyal, U. and Baral, R. (2010). Neem leaf glycoprotein matures myeloid derived dendritic cells and optimizes anti-tumor $\mathrm{T}$ cell functions. Vaccine, 28(5):1241-1252.

Gruhlke, M.C.; Nicco, C.; Batteux, F. and Slusarenko, A.J. (2016). The effects of allicin, a reactive sulfur species from garlic, on a selection of mammalian cell lines. Antioxidants, 6:1-7

Guan, Y.; Zheng, B.J.; He, Y.Q.; Liu, X.L.; Zhuang, Z.X.; Cheung, C.L. and Guan, Y.J. (2003). Isolation and characterization of viruses related to the SARS coronavirus from animals in southern China. Science, 302:276-278

Han, X. and Parker, T.L. (2017). Anti-inflammatory activity of clove (Eugenia caryophyllata) essential oil in human dermal fibroblasts. Pharmaceutical Biology, 55(1):1619-1622.

Hemida, M.G.; Perera, R.A.; Wang, P.; Alhammadi, M.A.; Siu, L.Y.; Li, M and Peiris, M. (2013). Middle East respiratory syndrome (MERS) coronavirus seroprevalence in domestic livestock in Saudi Arabia, 2010 to 2013. Euro Surveillance, 18:21-27.

Hong Kong Centre for Health Protection (2020). Countries/areas with reported cases of novel. Retrieved from https://www.chp.gov.hk/ files/pdf/statistics_of_the_cases_novel_coronavirus_infection_en.pdf

Hossein, M.B.; Rana, K.; Saeed, K.; Yousef, D. and Mohammad, R.K. (2011). Potential immunomodulation effect of the extract of Nigella sativa on ovalbumin sensitized guinea pigs. Biomed and Biotechnol, 12(3):201-209

Hu, B.; Zeng, L.P.; Yang, X.L.; Ge, X.Y.; Zhang, W.; Li, B. and Shi, Z.L. (2017). Discovery of a rich gene pool of bat SARS- related coronaviruses provides new insights into the origin of SARS coronavirus. PLoS Pathogens, 13:e1006698.

Huang, C.; Wang, Y.; Li, X.; Ren, L.; Zhao, J.; Hu, Y.; Zhang, L.; Fan, G.; Xu, J. and Gu, X. (2006). Macrophage mediated inhibitory effect of Zingiber officinale Rosc, a traditional oriental herbal medicine, on the growth of influenza A/Aichi/2/68 virus. 34(1):157-169.

Iuvone, T.; Esposito, F. G. and Capasso, I.A. (2003). Induction of nitric oxide synthase expression by Withania somnifera in macrophages. Life Sci., 72(14):1617-1625

Jain, J.; Narayanan, V.; Chaturvedi, S.; Pai, S. and Sunil, S. (2018). In vivo evaluation of Withania somnifera-based Indian traditional formulation (Amukkara Choornam), against Chikungunya virusinduced morbidity and arthralgia. Journal of Evidence-Based Integrative Medicine, 23:2156587218757661. https://doi.org/ $10.1177 / 2156587218757661$

Jayawardena, R.; Sooriyaarachchi, P.; Chourdakis, M.; Jeewandarae, C. and Ranasinghe, $\mathbf{P}$ (2020). Enhancing immunity in viral infections, with special emphasis on COVID-19: A review. Diabetes and Metabolic Syndrome: Clinical Research and Reviews, 14(4):367-382.

Jeba, R. C.; Vaidyanathan, R. and Rameshkumar, G. (2011). Immunomodulatory activity of aqueous extract of Ocimum sanctum in rat. International Journal on Pharmaceutical and Biomedical Research (IJPBR), 2(1):33-38.

Jeong, Y.Y.; Ryu, J.H.; Shin, J.H.; Kang, M.J.; Kang, J.R.; Han, J. and Kang, D. (2016). Comparison of anti-oxidant and anti-Inflammatory effects between fresh and aged black garlic extracts. Molecules, 21:430-441

Kaihatsu, K.; Yamabe, M. and Ebara, Y. (2018). Antiviral mechanism of action of epigallocatechin-3-O-gallate and its fatty acid esters. Molecules, 23:2475.
Kandeel, M. and Al-Nazawi, M. (2020). Virtual screening and repurposing of FDA approved drugs against COVID-19 main protease. Life Sci., 251:117627. https://doi.org/10.1016/j.lfs.2020.117627.

Kapil, S. and Sharma, S. (1997). Immunopotentiating compounds from Tinospora cordifolia. Journal of Ethnopharmacology, 16:89-95.

Khan, Adnan A.; Khan, Shiba.; Khan, Unaiza and Das, Kuntal. (2020). The COVID-19 pandemic and its implications on research. Ann. Phytomed., 9(1):18-26. http://dx.doi.org/10.21276/ap.2020.9.1.3

Khanna, K.; Kohli, S.K.; Kaur, R.; Bhardwaj, A.; Bhardwaj, V.; Ohri, P.; Sharma, A.; Ahmad, A. and Ahmad, A. (2020). Herbal immune-boosters: Substantial warriors of pandemic COVID-19 battle. Phytomedicine, https://doi.org/10.1016/j.phymed.2020.153361

Koch, C.; Reichling, J.; Schneele, J. and Schnitzler, P. (2008). Inhibitory effect of essential oils against herpes simplex virus type 2 . Phytomedicine, 15(1):71-78.

Koshak, A.E. and Koshak E.A. (2020). Nigella sativa L. as a potential phytotherapy for coronavirus disease 2019: A mini review of in silico studies. Current Therapeutic Research, 93:100602. https://doi.org/ $10.1016 /$ j.curtheres.2020.100602

Krupanidhi, S.; Peele, A.; Venkateswarulu,T.C.; Ayyagari,V.S.; Md. Nazneen Bobby.; John B.D.; Narayana, A.V. and Aishwarya, G. (2020). Screening of phytochemical compounds of Tinospora cordifolia for their inhibitory activity on SARS-CoV-2: An in silico study. Journal of Biomolecular Structure and Dynamics. https://doi.org/ $10.1080 / 07391102.2020 .1787226$

Kulkarni, R. A. and Deshpande, A. R. (2016). Anti-inflammatory and antioxidant effect of ginger in tuberculosis. Journal of Complementary and Integrative Medicine, 13(2):201-206.

Kumar, S. and Pandey, A.K. (2013). Chemistry and biological activities of flavonoids: An overview. Lancet, 395(10223):497-506.

Lee, J.W.; Ryu, H. W.; Park, S.Y.; Park, H.A.; Kwon, O.K.; Yuk, H.J. and Ahn, K.S. (2017). Protective effects of neem (Azadirachta indica A. Juss.) leaf extract against cigarette smoke and lipopolysaccharideinduced pulmonary inflammation. International Journal of Molecular Medicine, 40(6):1932-1940.

Li, Q.; Guan, X.; Wu, P.; Wang, X.; Zhou, L.; Tong, Y. and Feng, Z. (2020). Early transmission dynamics in Wuhan, China, of novel coronavirus infected pneumonia. New England Journal of Medicine, 382:1199-1207.

Mahmood, N.A. and Barkat, A.K. (2010). The morphology, characteristics, and medicinal properties of Camellia sinensis' tea. Journal of Medicinal Plants Research, 4(19):2028-2033.

Mair, C.E.; Liu, R.; Atanasov, A.G.; Schmidtke, M.; Dirsch, V.M. and Rollinger, J.M. (2016). Antiviral and anti-proliferative in vitro activities of piperamides from black pepper. Planta Med., 82:S1-S381.

Majdalawieh, A.F. and Carr R.I. (2010). In vitro investigation of the potential immunomodulatory and anticancer activities of black pepper (Piper nigrum) and cardamom (Elettaria cardamomum). J. Med. Food, 13:371-381.

Mao, Q.Q.; Xu, X.Y.; Cao, S.Y.; Gan, R.Y.; Corke, H. and Beta, T. (2019). Bioactive compounds and bioactivities of ginger (Zingiber officinale Roscoe). Foods, Basel, Switzerland, 8(6):185

Maurya, V.K.; Kumar, S.; Prasad, A.K.; Bhatt, M.L. and Saxena, S.K. (2020). Structure-based drug designing for potential antiviral activity of selected natural products from Ayurveda against SARS-CoV-2 spike glycoprotein and its cellular receptor. Virus Disease, 31(2):179-193. 
Maurya, D. and Sharma, D. (2020). Evaluation of traditional Ayurvedic preparation for prevention and management of the novel coronavirus (SARS-CoV-2) using molecular docking approach. Preprint. https://doi.org/10.26434/chemrxiv.12110214.v1

Mediratta, P.K.; Sharma, K.K. and Singh, B (2002). Evaluation of immunomodulatory potential of Ocimum sanctum seed oil and its possible mechanism of action. Journal of Ethnopharmacology, 80:15-20.

Meena, A.K.; Singh, A. and Rao, M.M. (2010). Evaluation of physicochemical and preliminary phytochemical studies on the fruit of emblica officinalis gaertn. Asian Journal of Pharmaceutical and Clinical Research, 3(3):242-43.

Menegazzi, M.; Campagnari, M.; Bertoldi, M. and Crupi, R. (2020). Protective effect of epigallocatechin-3-gallate (EGCG) in diseases with uncontrolled immune activation: Could such a scenario be helpful to counteract COVID-19? Int. J. Mol. Sci., 21:5171. doi:10.3390/ijms21145171

Ministry of Ayush (2020). Ayurveda's immunity boosting measures for self care during COVID-19 crisis. https://www.ayush.gov.in/docs/ 123.pdf.

Mittal, M.; Gupta, N.; Parashar, P.; Mehra, V. and Khatri, M. (2014) Phytochemical evaluation and pharmacological activity of Syzygium aromaticum: A comprehensive review. Int. J. Pharm. Pharm. Sci., 6(8):67-72.

Mondal, S.; Varma, S.; Bamola, V.D.; Naik, S.N.; Mirdha, B.R. and Padhi, M.M. (2011). Double-blinded randomized controlled trial for immunomodulatory effects of tulsi (Ocimum sanctum Linn.) leaf extract on healthy volunteers. Journal of Ethnopharmacology, 136(3):452-456.

Muhammad, F.A.K.; Rongrong, L.; Khalid, M.; Muhammad, W.; Kun, L. and Jiakui, L. (2020). Potential influence of Nigella sativa (Black cumin) in reinforcing immune system: A hope to decelerate the COVID-19 pandemic. Phytomedicine, https://doi.org/10.1016/ j.phymed.2020.153277

Mukherjee, R.; Dash, P. and Ram, G. (2005). Immunotherapeutic potential of Ocimum sanctum (L.) in bovine subclinical mastitis. Res. Vet. Sci., 79:37-43.

Munagala, R.; Kausar, H.; Munjal, C. and Gupta, R.C. (2011). Withaferin a Induces p53-dependent apoptosis by repression of HPV oncogenes and upregulation of tumor suppressor proteins in human cervical cancer cells. Carcinogenesis, 32:1697-1705. https://doi.org/ $10.1093 /$ carcin/bgr 192

Nilea, S.H.; Nileb, A.; Gansukhb, H.; Baskarc, B. and Ka, G. (2017) Subcritical water extraction of withanosides and withanolides from ashwagandha (Withania somnifera L.) and their biological activities. Food and Chemical Technology, pp:132. https://doi.org/10.1016/ j.fct.2019.110659 R

Pandey, G.; Verma, K.K. and Singh, M. (2014). Evaluation of phytochemical, antibacterial and free radical scavenging properties of Azadirachta indica (neem) leaves. Int. J. Pharm. Pharm. Sci., 6(2):444-447.

Pant, M.; Ambwani, T. and Umapathi, V. (2012). Antiviral activity of ashwagandha extract on infectious bursal disease virus replication. Indian Journal of Science and Technology, 5:2750-2751.

Parasuraman, S.; Thing, G.S. and Dhanaraj, S.A. (2014). Polyherbal formulation: Concept of ayurveda. Pharm. Rev., 8(16):73.

Pastorino, G.; Corna, l.; Soares, S.; Rodrigues, F. and Oliveira, M.B. (2020). Liquorice (Glycyrrhiza glabra): A phytochemical and pharmacological review. Phytotherapy Research, 32:2323-2339.
Patwardhan, B.; Chavan-Gautam, P.; Gautam, M.; Tillu, G. and Chopra, A. (2020). Ayurveda rasayana in prophylaxis of COVID-19, Current Science, 118:1-3.

Pius, T.; Mpiana.; Koto-Te-Nyiwa, Ngbolua.; Damien, S.T. Tshibangu.; Jason T. Kilembe.; Benjamin, Z. G.; Domaine, T. M.; Clement, L. I.; Emmanuel, M. L.; Clement, M. M.; Aristote M.; Gedeon, N. B. and Dorothée D. T. (2020a). Aloe vera (L.) Burm. F. as a potential anti-COVID-19 plant: A mini-review of its antiviral activity. European Journal of Medicinal Plants, 31(8):86-93. Article no.EJMP.56842.

Pius, T.; Mpiana.; Koto-Te-Nyiwa Ngbolua.; Damien, S. T. Tshibangu.; Jason T. Kilembe.; Benjamin, Z. G.; Domaine, T. M.; Clement, L. I.; Emmanuel, M. L.; Clement,M. M.; Aristote M.; Gedeon, N. B. and Dorothée D. T. (2020b). Identification of potential inhibitors of SARS-CoV-2 main protease from Aloe vera compounds: A molecular docking study. Chemical Physics Letters, 754:137751 doi: doi.org/10.1016/j.cplett.2020.137751

Popuri, A.K. and Pagala, B. (2013). Extraction of curcumin from turmeric roots. Int. J. Innovative Res. Stud., 2(5):290-299.

Prakash, P. and Gupta, N. (2005). Therapeutic uses of Ocimum sanctum Linn (Tulsi) with a note on eugenol and its pharmacological actions: A short review. Indian Journal of Physiology and Pharmacology, 49(2): $125-131$.

Prasad, K.; Fatima, K.; Summya, R.; Ali, N.; Abdullah, F.A.; Mohammad, Z.A.; Ali, S.; Mohammed, S.; Alqahtani and Kumara, V. (2020). Targeting hub genes and pathways of innate immune response in COVID-19: A network biology perspective. Int. J. Biol. Macromol., 15(163):1-8.

Prasad, S. and Aggarwal, B.B. (2011). Turmeric, the golden spice: From traditional medicine to modern medicine. In: Benzie IFF, WachtelGalor S, editors. Herbal medicine: Biomolecular and clinical aspects. 2nd ed. Boca Raton (FL): CRC Press/Taylor and Francis, pp:13.

Prompetchara, E.; Ketloy, C. and Palaga, T. (2020). Immune responses in COVID-19 and potential vaccines: Lessons learned from SARS and MERS epidemic. Asian Pac. J. Allergy Immunol., 38:1-9.

Pundarikakshudu, K. and Kanaki, N.S. (2019). Analysis and regulation of traditional Indian medicines (TIM). J. AOAC Int., 102(4):977-978.

Qin, C.; Zhou, L.; Hu, Z.; Zhang, S.; Yang, S.; Tao, Y.; Xie, C.; Ma, K.; Shang, K.; Wang, W. and Tian, D.S. (2020). Dysregulation of immune response in patients with COVID-19 in Wuhan, China. Clin. Infect. Dis., pii, ciaa, pp:248. 10.1093/cid/ciaa248.

Rajagopal, K.; Byran, G.; Jupudi, S. and Vadivelan R. (2020). Activity of phytochemical constituents of black pepper, ginger, and garlic against coronavirus (COVID-19): An in silico approach. Int. J. Health Allied. Sci., 9(5):43-50.

Rajalakshmi, S. and Sivanandam, G. (1986). Role of Tulsi (Ocimum sanctum Linn.) in the management of Manjal Kamalai (viral hepatitis). Journal of Research in Ayurveda and Siddha, 9(3-4):118-123.

Raman G. and Gaikar, V.G. (2002). Extraction of piperine from Piper nigrum (Black pepper) by hydrotropic solubilization. Ind. Eng. Chem. Res., 41:2966-2976.

Rampogu, S.; Baek, A.; Gajula, R.G.; Zeb, A.; Bavi1, R.S.; Kumar, R.; Kim, Y.; Kwon, Y.J. and Lee, K.W. (2018). Ginger (Zingiber offcinale) phytochemicals-gingerenone: A and shogaol inhibit SaHPPK: molecular docking, molecular dynamics simulations and in vitro approaches. Ann. Clin. Microbiol. Antimicrob., 17(16). https:// doi.org/10.1186/s12941-018-0266-9

Rasool, M. and Varalakshmi, P. (2009). Immunomodulatory role of Withania somnifera root powder on experimental induced inflammation: An in vivo and in vitro study. Vascul. Pharmacol. 44(6):406-410. 
Reichling, J.; Schnitzler, P.; Suschke, U. and Saller, R. (2009). Essential oils of aromatic plants with antibacterial, antifungal, antiviral, and cytotoxic properties: An overview. Forsch. Komplementmed. 16:79-90.

Rizwanul, B.B.H.; Haque, S.P.; Pandey, S.; Sayeed, S.I. and Raisuddin, S. (2003). Immunomodulatory effects of fenugreek (Trigonella foenum graecum L.) extract in mice. International Immunopharmacology, 3(2):257-265.

Rodrigo, A.; Fabián, S.Q.; Rocío, I.; Enrique, O.F.G.; Juan, P.R.G. and Lucrecia, C.A. (2015). Immunomodulation and anti-inflammatory effects of garlic compounds. Journal of Immunology Research, pp:401630. http://dx.doi.org/10.1155/2015/401630

Roy, S. and Bhattacharyya, P. (2020). Possible role of traditiona medicinal plant Neem (Azadirachta indica) for the management of COVID-19 infection. Int. J. Res. Pharm. Sci., 11(SPL)(2):122-125.

Sagar, A.; Vasanthkumar, K. and Arun, H.S. (2020). Efficacy of natural compounds from Tinospora cordifolia against SARS-CoV-2 protease, surface glycoprotein and RNA polymerase. Virology, pp:1-10. $10.21203 /$ rs.3.rs-27375/v1

Sai Ram, M.; Neetu, B.; Yogesh, B.; Anju, P.; Dipti, T.; Pauline, S.K.; Sharma, S.K.S.; Sarada, G.; Kumar, I.D. and Selvamurthy, W. (2020) Cyto-protective and immunomodulating properties of amla (Emblica officinalis) on lymphocytes: An in vitro study. Journal of Ethnopharmacology, 81:5-10.

Salehi, B.; Konovalov, D. A.; Fru, P.; Kapewangolo, P.; Peron, G.; Ksenija M. S. and Sharifi-Rad, J. (2020). Areca catechu: From farm to food and biomedical applications. Phytotherapy Research, 1:https:// doi.org/10.1002/ptr.6665

Salehi, B.; Krochmal-Marczak, B.; Skiba, D.; Patra, J. K.; Das, J. K.; Das, G. and Martorell, M. (2019a). Convolvulus plant: A comprehensive review from phytochemical composition to pharmacy. Phytotherapy Research, pp:(34):315-328.

Sell, S. (1980). Arthus (toxic complex) reaction. In: Immunology immunopathology and immunity, 3rd ed. Harper and Row, Hagerstown, pp:242-283.

Sen, D.; Debnath, P.; Debnath, B.; Bhaumik, S. and Debnath, S. (2020) Identification of potential inhibitors of SARS-CoV-2 main protease and spike receptor from 10 important spices through structurebased virtual screening and molecular dynamic study, Journal of Biomolecular Structure and Dynamics, doi: 10.1080/07391102. 2020.1819883

Sharifi-Rad, J.; Melgar L.G.; Hernández A. J.; Taheri, Y.; Shaheen, S.; Kregiel, D. and Martins, N. (2019). Malva species: Insights on its chemical composition towards pharmacological applications. Phytotherapy Research, 34:564-567.

Sharma, P.; Dwivedee, B.P.; Bisht, D.; Das, A.K. and Kumar, D. (2019) The chemical constituents and diverse pharmacological importance of Tinospora cordifolia. Helion, 5(9). https://doi.org/10.1016/ j.heliyon.2019.e02437

Sharrif, M.M. and Sandeep, K.V. (2011). Aloe vera their chemicals composition and applications: A review. Int. J. Biol. Med. Res., 2(1):466-471

Shelton, R.M. (1991). Aloe vera: Its chemical and therapeutic properties Int. J. Dermatol., 30(10):679-683.

Shi, T.; Wilhelm, E.; Bell, B. and Dumais, N. (2016). Nf-kb-dependent inhibition of HIV-1 transcription by Withaferin A. Current HIV Research, 2:1-8. https://doi.org/10.4172/2572-0805.1000119
Shivananjappa, M. and Joshi, M. (2012). Aqueous extract of tulsi (Ocimum sanctum) enhances endogenous antioxidant defenses of human hepatoma cell line (HepG2). Journal of Herbs, Spices and Medicinal Plants, 18(4):331-348.

Shree, P.; Mishra, P.; Selvaraj, C.; Kumar, S.; Chaube, R.; Garg, N. and Tripathia, Y.B. (2020). Targeting COVID-19 (SARS-CoV-2) main protease through active phytochemicals of ayurvedic medicinal plants, Withania somnifera (Ashwagandha), Tinospora cordifolia (Giloy) and Ocimum sanctum (Tulsi): A molecular docking study. J. Biomol. Struct. Dyn., pp:1-14. doi: 10.1080/07391102.2020.1810778

Si, X.; Wang, Y.; Wong, J.; Zhang, J.; McManus, B.M. and Luo, H. (2007). Dysregulation of the ubiquitin-proteasome system by curcumin suppresses coxsackievirus B3 replication. Journal of Virology, 81(7):3142-3150.

Sierra, G.D.; Rocío, Castro-Ríosc; Azucena, González-Hortaa; Jorge, Lara-Ariasb and Abelardo, Chávez-Montesa (2014). Acemannan, an extracted polysaccharide from Aloe vera: A literature review. Natural Products Communication, 9(8):1217-1221.

Singh, D. and Chaudhuri, P.K. (2018). A review on phytochemical and pharmacological properties of Holy basil (Ocimum sanctum L.) Indust. Crops and Products, 32(3):67-382.

Singh, R.; Gautam, A.; Chandel, S.; Ghosh, A.; Dey, D.; Roy, S.; Ravichandiran, V. and Ghosh, D. (2020). Protease inhibitory effect of natural polyphenolic compounds on SARS-CoV-2: An in silico Study. Molecules, 25:4604. doi: 10.3390/molecules25204604

Slimestad, R.; Fossen, T. and Vagen, I.M. (2007). Onions: A source of unique dietary flavonoids. Journal of Agricultural and Food Chemistry, 55:10067-10080.

Soni, V.K.; Mehta, A.; Ratre, Y.K.; Tiwari, A.K.; Amit, A.; Singh, A.P.; Sonkar, S.C.; Chaturvedi, N.; Shukla, D. and Vishvakarma, N.K. (2020). Curcumin, a traditional spice component, can hold the promise against COVID-19? European Journal of Pharmacology, 886:173551. https://doi.org/10.1016/j.ejphar.2020.173551

Srinivasan, K. (2006). Fenugreek (Trigonella foenum-graecum): A review of health beneficial physiological effects. Food Reviews International, 22:203-224.

Srinivasan, K. (2018). Cumin (Cuminum cyminum) and black cumin (Nigella sativa) seeds: Traditional uses, chemical constituents, and nutraceutical effects. Food Quality and Safety, 2:1-16. doi: $10.1093 /$ fqsafe/fyx 031

Srivastava Niraj and Saxena Varsha (2020). A review on scope of immunomodulatory drugs in Ayurveda for prevention and treatment of Covid-19. Plant Science Today, 7(3):417-423.

Steinmann, J.; Buer, J.; Pietschmann, T. and Steinmann, E. (2013). Anti-infective properties of epigallocatechin-3-gallate (EGCG), a component of green tea. Br. J. Pharmacol., 168:1059-1073.

Street, R.; Szakova, J.; Drabek, O. and Mladkova, L. (2006). The status of micronutrients $(\mathrm{Cu}, \mathrm{Fe}, \mathrm{Mn}, \mathrm{Zn})$ in tea and tea infusions in selected samples imported to the Czech Republic. Czech J. Food Sci., 24:62-71

Sun, C.P.; Qiu, C.Y.; Yuan, T.; Nie, X.F.; Sun, H.X.; Zhang, Q.; Li ,H.X.; Ding, L.Q.; Zhao, F.; Chen, L.X. and Qiu F. (2016). Antiproliferative and anti-infammatory Withanolides from Physalis angulata. J. Nat. Prod., 79(6):1586-1597.

Tabuti, J.R.; Lye, K.A. and Dhillion, S.S. (2003). Traditional herbal drugs of Bulamogi, Uganda: Plants, use and administration. J. Ethnopharmacol., 88(1): 19-44 
Tai-Nin Chow, J.; Williamson, D.A.; Yates, K.M. and Goux, W. (2005) Chemical characterization of the immunomodulating polysaccharide of Aloe vera L. Carbohydrate Research, 340:1131-1142.

Thevarajan, I.; Nguyen, T.H.O.; Koutsakos, M.; Druce, J.; Caly, L.; van de Sandt, C.E.; Jia, X.; Nicholson, S.; Catton, M.; Cowie, B.; Tong, S.Y.C.; Lewin, S.R.; Kedzierska, K.; Tiwari, V.; Darmani, N.A.; Yue, B.Y. and Shukla, D. (2013). In vitro antiviral activity of neem (Azadirachta indica L.) bark extract against herpes simplex virus type-1 infection. Phytother. Res., 24(8):1132-1140.

Tripathia, M.K.; Singh, P.; Sharma, S.; Tej, P.; Singha, A.; Ethayathulla, S. and Kaura, P. (2020). Identification of bioactive molecule from Withania somnifera (Ashwagandha) as SARS-CoV-2 main protease inhibitor. Journal of Biomolecular Structure and Dynamics, https:/ /doi.org/10.1080/07391102.2020.1790425

Upadhyaya, R.; Pandey, R.P.; Sharma, V. and Verma A.K. (2020). Assessment of the multifaceted immunomodulatory potential of the aqueous extract of Tinospora cordifolia. Research Journal of Chemical Sciences, 1(6):71-79.

Varshney, K.; Varshney, M. and Nath B. (2020). Molecular modeling of isolated phytochemicals from Ocimum sanctum towards exploring potential inhibitors of SARS coronavirus main protease and papainlike protease to treat COVID-19. https://ssrn.com/abstract=3554371

Venkata, K.N.; Swaroop, A.; Bagchi, D. and Bishayee, A. (2017). A small plant with big benefits: Fenugreek (Trigonella foenum-graecum Linn.) for disease prevention and health promotion. Mol. Nutr. Food Res., doi: 10.1002/mnfr.201600950

Vetvicka, V. and Vetvickova, J. (2011). Immune enhancing effects of WB365, a novel combination of Ashwagandha (Withania somnifera) and Maitake (Grifola frondosa) extracts. North American Journal of Medical Sciences, 3(7):320-324.

Wang, F.; Hou, H.; Luo, Y.; Tang, G.; Wu, S.; Huang, M.; Liu, W.; Zhu, Y.; Lin, Q.; Mao, L.; Fang, M.; Zhang, H. and Sun, Z. (2020a). The laboratory tests and host immunity of COVID-19 patients with different severity of illness. JCI Insight, pp:137799. https://doi.org/ 10.1172/jci.insight. 137799 .
Wang, Q.; Qian, Y.; Wang, Q.; Yang, Y. f.; Ji, S.; Song, W. and Ye, M. (2015). Metabolites identification of bioactive licorice compounds in rats. Journal of Pharmaceutical and Biomedical Analysis, 115:515-522.

WHO (2020). Pneumonia of unknown cause in China. Retrieved from https://www.who.int/csr/don/05-january-2020-pneumonia-ofunkowncause-china/en/

Wu, C.; Liu, Y.; Yang, Y.; Zhang, P.; Zhong, W. and Wang, Y. (2020). Analysis of therapeutic targets for SARS-CoV-2 and discovery of potential drugs by computational methods, The Lancet, 395(10228): 949-950.

Xiong, Y.; Liu, Y.; Cao, L.; Wang, D.; Guo, M.; Jiang, A.; Guo, D.; Hu, W.; Yang, J.; Tang, Z.; Wu, H.; Lin, Y.; Zhang, M.; Zhang, Q.; Shi, M.; Zhou, Y.; Lan, K. and Chen, Y. (2020). Transcriptomic characteristics of bronchoalveolar lavage fluid and peripheral blood mononuclear cells in COVID-19 patients. Emerg. Microbes Infect., 9(1):761-770.

Xu, J.; Xu, Z. and Zheng, W.A. (2017). Review of the antiviral role of green tea catechins. Molecules, 22:1337.

Yang, X.; Yu, Y.; Xu, J.; Shu, H.; Xia, J.; Liu, H.; Wu, Y.; Zhang, L.; Yu, Z.; Fang, M.; Yu, T.; Wang, Y.; Pan, S.; Zou, X.; Yuan, S. and Shang, Y. (2020). Clinical course and outcomes of critically ill patients with SARS-CoV-2 pneumonia in Wuhan, China: A single-centered, retrospective, observational study. Lancet Respir. Med., S2213-2600(20)30079-5. https://doi.org/10.1016/S2213-2600(20)30079-5.

Yates, K.M.; Rosenberg, L.J.; Harris, C.K.; Bronstad, D.C.; King, G.K.; Biehle, G.A.; Walker, B.; Ford, C.R.; Hall, J.E. and Tizard, I.R. (1992). Pilot study of the effect of acemannan in cats infected with feline immunodeficiency virus. Veterinary Immunology and ImmunoPathology, 35:177-189

Zahid, J.; Muhammad, Y.; ur Rehman, M.; Azhar, M.; Rashad, M.; Khushi, M.; Roshan, A.K. and Izhar, H.Q. (2013). Effect of neem leaves (Azadirachta indica) on immunity of commercial broilers against new castle disease and infectious bursal disease. African Journal of Agricultural Research, 8(36):4596-4603.

Citation Nupur Mehrotra (2020). Medicinal plants, aromatic herbs and spices as potent immunity defenders: Antiviral (COVID-19) perspectives. Ann. Phytomed., 9(2):30-49. http://dx.doi.org/10.21276/ap.2020.9.2.4 